\title{
Nitric Acid Extraction into a TODGA Solvent Modified with Octanol
}

David Woodhead, ${ }^{\mathrm{a}}$ Fiona McLachlan, ${ }^{\mathrm{b}}$ Robin Taylor, ${ }^{\mathrm{a}}$ Udo Müllich, ${ }^{\mathrm{c}}$ Andreas Geist, ${ }^{\mathrm{c}}$ Andreas Wilden, ${ }^{\mathrm{d}}$ Giuseppe Modolo ${ }^{\mathrm{d}}$

a National Nuclear Laboratory, Central Laboratory, Sellafield, CA20 1PG, United Kingdom

b National Nuclear Laboratory, Building D5, Culham Science Centre, Abingdon, Oxfordshire, OX14 3DB, United Kingdom

${ }^{c}$ Karlsruhe Institute of Technology (KIT), Institute for Nuclear Waste Disposal (INE), Karlsruhe, Germany

${ }^{d}$ Forschungszentrum Jülich GmbH, Institut für Energie- und Klimaforschung - Nukleare Entsorgung und Reaktorsicherheit (IEK-6), Jülich, Germany

\section{Summary}

Distribution data for the partition of nitric acid between nitric acid solution and a solvent phase comprising various combinations of TODGA, octanol and inert kerosene diluent have been generated, covering a range of conditions from $0-9 \mathrm{~mol} / \mathrm{L} \mathrm{HNO}_{3}(\mathrm{aq}), 0-100 \%$ octanol, $0-0.4 \mathrm{~mol} / \mathrm{L}$ TODGA over a temperature range from $10-50{ }^{\circ} \mathrm{C}$. The data have been used to derive a model describing the nitric acid equilibrium between the phases suitable for incorporation in process models of e.g. the innovative SANEX process. For the nitric acid / octanol / diluent system it was found that an accurate prediction of nitric acid distribution could be achieved using a model allowing 1:1, 1:2 and 1:3 nitric acid / octanol adducts. For the nitric acid / TODGA / diluent system the best models were found to be those allowing 4:1, 3:1, 2:1, 1:1 and 2:2 nitric acid / TODGA adducts. Superimposing the models for nitric acid distribution into the individual extractants and comparing with experimental results for the nitric acid / octanol / TODGA system showed systematic differences indicative of antagonistic and synergistic effects applying in the ranges $0.5-1.5 \mathrm{~mol} / \mathrm{L} \mathrm{HNO}_{3}$ and > $1.5 \mathrm{~mol} / \mathrm{L} \mathrm{HNO}_{3}$ respectively. These effects were modelled by the inclusion of $0: 1: 2,1: 1: 1$, 2:1:3 and 3:1:2 nitric acid / TODGA / octanol adducts. The effect of temperature on nitric acid extraction was well described by an Arrhenius type expression with an activation energy of $-25.7 \mathrm{~kJ} / \mathrm{mol}$. No diluent dependence was found for nitric acid extraction.

\section{Introduction}

In order to reduce the burden of radioactive waste for geological disposal it is desirable to be able to separate the minor actinides $(\mathrm{Np}, \mathrm{Am}, \mathrm{Cm})$ from the reprocessing waste stream. Removal of neptunium can be achieved by modification of the PUREX (Plutonium Uranium Reduction Extraction) process such that neptunium is initially routed with the uranium and plutonium $\left[{ }^{1-2}\right]$. The separation of americium and curium from fission products in general and lanthanides in particular is more challenging. TODGA $\left(N, N, N^{\prime}, N^{\prime}\right.$-tetra- $n$-octyl 
diglycolamide, Figure 1) has been identified as a promising extractant for the co-extraction of minor actinides and lanthanides from nitric acid based solution $\left.{ }^{3-4}\right]$, allowing these to be separated from other fission products. In a subsequent process, americium and curium are separated from lanthanides $\left[^{5}\right]$. This is achieved either by selectively stripping the former from the loaded TODGA solvent, employing an aqueous phase complexing agent such as polyaminocarboxylates $\left[{ }^{6-12}\right]$, sulphonated bis-triazinyl-pyridines $\left[{ }^{13-15}\right]$ or bis-triazolylpyridine $\left[{ }^{16-17}\right]$, or by selective extraction from the TODGA product solution, obtained after backwashing the actinides and lanthanides, using nitrogen- or sulphur donor extracting agents $\left[{ }^{5,18-21}\right]$.

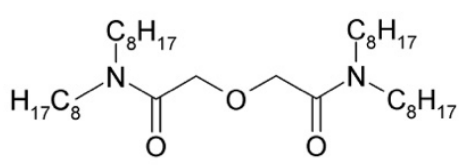

Figure 1: $N, N, N^{\prime}, N^{\prime}$-tetra- $n$-octyl diglycolamide (TODGA).

A known disadvantage of TODGA-diluent mixtures is the tendency to form a third phase with only moderate loadings of nitric acid and / or metal ions, the extent of this tendency being dependent on the exact choice of diluent $\left.{ }^{4,22}\right]$. In order to satisfactorily suppress third phase formation it is necessary to include a phase modifier in the formulation $\left[{ }^{4}\right]$. Various modifiers have been tried (e.g. tri-butyl phosphate $\left[{ }^{23-24}\right]$, lipophilic alcohols $\left[{ }^{25-26}\right]$, monoamides $\left[{ }^{27-29}\right], \quad$ DMDOHEMA ( $N, N^{\prime}$-dimethyl- $N, N^{\prime}$-dioctyl-2-(2-hexyloxy-ethyl)malonamide) $\left[{ }^{30-31}\right]$ ). A solvent comprising $0.2 \mathrm{~mol} / \mathrm{L}$ TODGA with $5 \mathrm{v} / \mathrm{v} \%$ octanol in an inert diluent such as odourless kerosene or hydrogenated tetra propylene (TPH) has been developed $\left[{ }^{32}\right]$ and used $\left[{ }^{14}\right]$ in recent European research programmes. This system has the advantage of employing only $\mathrm{CHON}$ species in the solvent, whilst keeping the amount of modifier at a small fraction of the overall solvent mix. However, both TODGA and octanol will extract nitric acid. In order to develop flowsheets using this solvent mix it is necessary to have a good understanding of nitric acid extraction as the distribution of nitric acid through a flow-sheet will be the prime determinant of solvent extraction behaviour within the plant. From a modelling perspective the development of good nitric acid extraction algorithms is a prerequisite for development of algorithms describing the extraction of other species present in the flow-sheet because all such algorithms must be designed to operate in the context of significant competition from nitric acid for the available extractant.

Nitric acid extraction into TODGA and similar diglycolamides is often described by assuming the formation of a $1: 1$ adduct, $\mathrm{HNO}_{3}$. TODGA $\left[{ }^{28}\right]$. This approximation is only sufficient to calculate nitric acid extraction at rather low aqueous nitric acid concentrations, see below. The formation of a $2: 1$ adduct, $2 \mathrm{HNO}_{3}$. TODGA at nitric acid concentrations exceeding $2 \mathrm{~mol} / \mathrm{L}$ is inferred from slope analysis $\left[{ }^{33}\right]$.

Nitric acid extraction from $0.1-3 \mathrm{~mol} / \mathrm{L}$ nitric acid into $0.01-0.2 \mathrm{~mol} / \mathrm{L}$ T2EHDGA $\left(N, N, N^{\prime}, N^{\prime}\right.$-tetra(2-ethylhexyl) diglycolamide) dissolved in $n$-dodecane was modelled accounting for the formation of $\mathrm{HNO}_{3} \cdot$ T2EHDGA and $2 \mathrm{HNO}_{3} \cdot \mathrm{T} 2 \mathrm{EHDGA}$ adducts $\left.{ }^{34}\right]$. Due to the absence of the modifier this model is not applicable to the TODGA $+5 \mathrm{v} / \mathrm{v} \%$ octanol 
solvent. Furthermore, we wished to extend the range of valid concentrations to $5 \mathrm{~mol} / \mathrm{L}$ nitric acid and $0.3 \mathrm{~mol} / \mathrm{L}$ TODGA.

The overall aim of this work was to establish reliable process models for calculating the distribution of nitric acid between a solvent containing TODGA with $5 \mathrm{v} / \mathrm{v} \%$ octanol in kerosene diluents. As such, aggregation phenomena which are described in the literature [35${ }^{36}$ ] are not taken into account, work described herein finding that no improvement in model accuracy can be obtained by the inclusion of TODGA aggregates.

\section{General Approach to Modelling}

In order to model the extraction of nitric acid into TODGA-octanol mixtures, the approach taken is the following: nitric acid extraction into TODGA and into octanol are modelled separately. Then by comparing experimental results for extraction of nitric acid in TODGAoctanol mixtures with results obtained by superimposing the TODGA and octanol models an assessment of any antagonistic and/or synergistic effects is made.

In order to facilitate practical use of the models it is desirable to construct them such that they have the widest possible range of validity. For most applications this is more important than attaining very high levels of accuracy over a narrow range of conditions. For reasons to do with ease of numerical solution it is also desirable to have the model behave in a physically plausible manner outside of the range of known validity. A model that allows physically implausible features such as negative stability constants, even if they would only occur outside the range of conditions being modelled, will tend to give rise to numerical problems as the software used to implement the model searches for a solution. It is also desirable to avoid discontinuities in models, particularly in the case of dynamic models in which changing conditions through the course of a run can result in such discontinuities being encountered many times through a run. Although modern process modelling software, such as gPROMS and Aspen Custom Modeler, supports the implementation of discontinuities most notably through the inclusion of "if ... then ... else" constructs, the use of these features will typically incur a heavy penalty in terms of reliability of the model and required run time. A common problem in poorly designed dynamic models is that they "chatter", continually switching between two states making no useful progress. For this reason, features such as conditional stability constants should be avoided wherever feasible.

The above considerations will tend to lead to a modelling approach which is semi-empirical, employing theory where possible, but utilising empirical approaches to cover gaps in the theoretical understanding. A theoretical underpinning will normally give rise to a model that is continuous and behaves in a physically plausible manner over a wide range of conditions. Empirical add-ons allow features such as solvent phase activities, which are typically incompletely understood, to be taken into consideration in the model. 


\section{Experimental}

The modelling approach followed requires experimental data for the extraction of nitric acid into octanol, TODGA and TODGA + octanol, each dissolved in kerosene. Furthermore, data with varying temperature are required for a complete description.

A dataset for the extraction of nitric acid into octanol-kerosene mixtures covering a range of acid $(0-5 \mathrm{~mol} / \mathrm{L})$ and octanol $(5-100 \mathrm{v} / \mathrm{v} \%)$ concentrations at $20{ }^{\circ} \mathrm{C}$ is available $\left[{ }^{37}\right]$, see Figure 2 and supporting information Table SI 1. It was verified that the kerosene used did not have a significant effect on nitric acid extraction. This is of importance since different kerosenes (Exxsol D80 and TPH) were used in further experiments.

Extraction data for nitric acid into TODGA or TODGA + mainly $5 \mathrm{v} / \mathrm{v} \%(0.32 \mathrm{~mol} / \mathrm{L})$ octanol were determined in three different laboratories to produce a robust dataset (see Tables SI 2 and SI 3). The procedures involved were as follows:

Aqueous phase was nitric acid $(0.1-9 \mathrm{~mol} / \mathrm{L})$. Organic phase was TODGA $(0.05-0.4 \mathrm{~mol} / \mathrm{L})$ in Exxsol D80 or TODGA $(0.05-0.3 \mathrm{~mol} / \mathrm{L})+$ octanol $(5 \mathrm{v} / \mathrm{v} \%)$ in TPH or Exxsol D80. Additional experiments with aqueous phase $\approx 2.8 \mathrm{~mol} / \mathrm{L} \mathrm{HNO}_{3}$, organic phase TODGA $(0.1-$ $0.3 \mathrm{~mol} / \mathrm{L})+\operatorname{octanol}(5-50 \mathrm{v} / \mathrm{v} \%)$ were undertaken. Equal volumes of aqueous and organic phase were contacted on an orbital shaker $(2500 / \mathrm{min})$ for 15 minutes (it was previously verified that equilibrium had been attained within several minutes) at $20 \pm 0.5^{\circ} \mathrm{C}, 22 \pm 1{ }^{\circ} \mathrm{C}$ or ambient $\left(\approx 20-25^{\circ} \mathrm{C}\right)$, depending on which of the labs involved performed the experiments. Following centrifugation, organic phase aliquots were stripped into water $(A / O$ $=1-4)$. Nitric acid concentrations were determined by duplicate potentiometric titration with $\mathrm{NaOH}(0.02-0.1 \mathrm{~mol} / \mathrm{L})$.

To quantify the temperature effect on nitric acid extraction, experiments were performed with TODGA $(0.1-0.2 \mathrm{~mol} / \mathrm{L})+\operatorname{octanol}(5 \mathrm{v} / \mathrm{v} \%)$ in $\mathrm{TPH}$ and $\mathrm{HNO}_{3}(0.1-3 \mathrm{~mol} / \mathrm{L})$ at various temperatures (controlled to $\pm 0.5^{\circ} \mathrm{C}$ at $10-50{ }^{\circ} \mathrm{C}$ ) (see Table SI 4). To avoid changing temperature during centrifugation and phase separation, a different experimental approach was followed: Samples were shaken in a temperature-controlled water bath. The samples were kept in the water bath over night for phase disengagement.

TODGA was synthesised according to reference $\left[{ }^{38}\right]$ or bought from Technocomm, UK. Exxsol D80 ("odourless kerosene", ExxonMobil), TPH (hydrogenated tetrapropylene, Prochrom, France) and octanol (puriss.) were used as received. Nitric acid 65\% (Merck, p.a.) was diluted to the desired concentration, which was determined by potentiometric titration with $0.1 \mathrm{~mol} / \mathrm{L} \mathrm{NaOH}$.

\section{Extraction of Nitric Acid into Octanol}

Various attempts have previously been made to model the data reported in reference $\left[{ }^{37}\right]$. A model based on Specific Ion Interaction Theory (SIT) $\left.{ }^{39}\right]$ gave good predictions of organic phase acid concentrations, assuming that the acid was extracted as $\mathrm{HNO}_{3} \cdot 2 \mathrm{Octanol}$ only $\left[{ }^{37}\right]$. This model was, however, limited in that different equilibrium constants for each octanol 
concentration considered had to be used. By taking only one starting octanol concentration at a time, the range of free octanol concentrations considered in fitting each of the equilibrium constants was very limited with the consequence that the dependence of acid extraction on the free octanol (and by implication the determination of the solvent phase acid adduct(s)) will be subject to significant uncertainty. From a practical perspective the inclusion of conditional stability constants is highly undesirable and a model that is not dependent on these is to be preferred.

Preliminary work on the modelling of these data considered a system with possible adducts $2 \mathrm{HNO}_{3} \cdot$ Octanol, $\mathrm{HNO}_{3} \cdot$ Octanol and $\mathrm{HNO}_{3} \cdot 2 \mathrm{Octanol}$, similar to what was found for $\mathrm{HNO}_{3}$ extraction into TBP $\left[{ }^{40}\right]$. When considering only one starting octanol concentration at a time it was found that $\beta_{12}>\beta_{11}, \beta_{21}$ suggesting, in line with reference, $\left[{ }^{37}\right]$ that only the $\mathrm{HNO}_{3} \cdot 2 \mathrm{Octanol}$ adduct is significant. However, when the dataset as a whole was considered it was found that the best fit was obtained with $\beta_{11}>\beta_{12}>>\beta_{21}$, so that the significant adducts are $\mathrm{HNO}_{3}$. Octanol and $\mathrm{HNO}_{3} \cdot 2$ Octanol, the former being more prevalent under most conditions. The resultant model gave acceptable results over most of the range covered by the data but predictions tended to lose accuracy near the ends of the acidity range, notably overstating extraction by $\approx 25 \%$ for $\left[\mathrm{HNO}_{3}\right]_{\mathrm{aq}}>4 \mathrm{~mol} / \mathrm{L}$. The inclusion of a $3 \mathrm{HNO}_{3} \cdot \mathrm{Octanol}$ adduct was also considered, but this was found to offer no benefit. The dataset as a whole has thus been revisited with results as reported below.

\section{Theory}

The extraction of nitric acid into octanol is assumed to be governed by a number of equilibria of the form:

$$
n \mathrm{H}^{+}+n \mathrm{NO}_{3}{ }^{-}+m \text { Octanol } \rightleftharpoons n \mathrm{HNO}_{3} \cdot m \text { Octanol }
$$

With equilibrium constants defined as below

$$
\beta_{n m}=\frac{\gamma_{n H N O_{3} . m o c t a n o l}\left[n \mathrm{HNO}_{3} . \text { mOctanol }\right]}{\gamma_{\mathrm{H}^{+}}^{n}\left[\mathrm{H}^{+}\right]^{n} \gamma_{\mathrm{NO}}^{n}\left[\mathrm{NO}_{3}^{-}\right]^{n} \gamma_{\text {Octanol }}^{m}[\text { Octanol }]}
$$

The concentration of octanol is the concentration of unbound (free) octanol. As the concentrations are expressed as molarities, the activity coefficients will be molar activity coefficients.

A number of simplifications are then made. In light of the lack of availability of data, the organic phase activity coefficients are taken to be unity and, in the aqueous phase, the mean stoichiometric activity coefficient for nitric acid $\left(\gamma_{\mathrm{s}}\right)$ is used instead of the activity coefficients of the individual ions. $\gamma_{\mathrm{s}}$ is related to the individual activity coefficients as in below in which $\alpha$ is the degree of dissociation of nitric acid:

$$
\gamma_{S}^{2}=\alpha^{2} \gamma_{H^{+}} \gamma_{N O_{3}^{-}}
$$


Taking $\left[\mathrm{HNO}_{3}\right]$ to be the total of dissociated and molecular nitric acid, the organic phase acid concentration is then given by:

$$
\left[\mathrm{HNO}_{3}\right]_{(\mathrm{org})}=\sum_{i=1}^{n} \sum_{j=1}^{m} i \beta_{i j} \gamma_{s}^{2 i}\left[\mathrm{HNO}_{3}\right]_{(\text {aq })}^{2 i}[\text { Octanol }]^{j}
$$

The final element of the model is a continuity equation for the extractant (octanol) which allows the amount of free extractant to be determined. This takes the form:

$$
[\text { Octanol }]_{(\text {total })}=[\text { Octanol }]+\sum_{i=1}^{n} \sum_{j=1}^{m} j \beta_{i j} \gamma_{s}^{2 i}\left[\mathrm{HNO}_{3}\right]_{(\text {aq })}^{2 i}[\text { Octanol }]^{j}
$$

In this equation [Octanol] (total) is the molar concentration of octanol in the unloaded solvent, while [Octanol] is the molar concentration of unbound octanol in the loaded solvent. By using molar concentrations this equation neglects dilation effects which would have the effect of reducing [Octanol] (total) as acid is taken up by the solvent. The neglect of dilation in this manner is a further simplification for which compensation is introduced in the empirical fitting process.

The modelling problem is then to find values for $\beta_{\mathrm{ij}}$ and an expression for $\gamma_{\mathrm{s}}$ such that a good fit is obtained to the experimentally determined data.

\section{Fitting of Correlation for Nitric Acid Distribution into Octanol}

Plotting $\left(\log \left[\mathrm{HNO}_{3}\right]_{\text {org }}-2 \log \left[\mathrm{HNO}_{3}\right]_{\text {aq }}\right)$ against $\log ([\mathrm{Octanol}])$ where [Octanol] is an estimate of the free octanol (rather than total octanol) yields a gradient of $\approx 1.4$, suggesting that the solvent contains a mix of $\mathrm{HNO}_{3} \cdot$ Octanol and $\mathrm{HNO}_{3} \cdot 2 \mathrm{Octanol}$ adducts. Scoping work indicated that there are benefits in terms of a fit if a $\mathrm{HNO}_{3} \cdot 3$ Octanol adduct is also considered, but no other candidate adducts were identified as potentially useful. In principle the expression for $\gamma_{\mathrm{s}}$ could be either derived from a fit to literature activity data or calculated using a technique such as SIT $\left[{ }^{39}\right]$ or Pitzer $\left[{ }^{41}\right]$ equations, but in practice the expression for $\gamma_{\mathrm{s}}$ is not a true activity coefficient as it takes account of a number of other unknowns such as solvent phase activities and to that extent it can be considered to be an empirically derived correlation. It is, however, useful to consider the available literature data as a starting point. Data from Gazith $\left[{ }^{42}\right]$ (original source $\left[{ }^{43}\right]$ ) for nitric acid activity coefficients were obtained and it was found that a good fit to these data could be obtained using an equation of the form:

$$
\begin{gathered}
\left.\gamma_{s}=\frac{A}{\left(\left[\mathrm{HNO}_{3}\right]\right.}+\mathrm{B}\right)^{n}+C+D\left[\mathrm{HNO}_{3}\right]+E\left[\mathrm{HNO}_{3}\right]^{2}+\mathrm{F}\left[\mathrm{HNO}_{3}\right]^{3} \\
+G\left[\mathrm{HNO}_{3}\right]^{4}
\end{gathered}
$$

Preliminary work suggested that setting $n=2, F=0$ and $G=0$ gives acceptable fits and the fitting procedure thereafter took these as constant.

Fitting was undertaken using gPROMS 5.1.1 parameter estimation $\left[{ }^{44}\right]$. As well as fitting the $\beta_{i j}$ and constants in equation 6 , gPROMS was also set up to estimate the variance of the 
experimental data. This was assumed to have a heteroscedastic distribution as described in Equation 7 below.

$$
\sigma=\omega|x|^{\gamma}
$$

where $\sigma$ is the standard deviation, $x$ is the measured value and $\omega$ and $\gamma$ are fitted constants, $\gamma=0$ corresponding to constant variance across the dataset, while $\gamma=1$ corresponds to constant relative variance. gPROMS performs the fitting by minimising the below objective function.

$$
\Phi=\frac{N}{2} \ln (2 \pi)+\frac{1}{2} \min _{\theta}\left\{\sum_{i=1}^{N E} \sum_{j=1}^{N V_{i}} \sum_{k=1}^{N M_{i j}}\left[\ln \left(\sigma_{i j k}^{2}\right)+\frac{\left(\tilde{z}_{i j k}-z_{i j k}\right)^{2}}{\sigma_{i j k}^{2}}\right]\right\}
$$

where $N$ is the total number of measurements taken in all experiments, $N E$ is the number of experiments performed, $N V_{i}$ is the number of variables measured in the $i^{\text {th }}$ experiment, $N M_{i j}$ is the number of measurements of the $j^{\text {th }}$ variable in the $i^{\text {th }}$ experiment, $\theta$ is the set of physical and variance model parameters to be determined, $\sigma_{i j k}^{2}$ is the variance of the $k^{\text {th }}$ measurement of the $j^{\text {th }}$ variable in the $i^{\text {th }}$ experiment, $\tilde{z}_{i j k}$ is the $k^{\text {th }}$ measured value of the $j^{\text {th }}$ variable in the $i^{\text {th }}$ experiment, $z_{i j k}$ is the $k^{\text {th }}$ model predicted value of the $j^{\text {th }}$ variable in the $i^{\text {th }}$ experiment. For the fitting undertaken here the data series was considered as a single dynamic experiment in which equilibrium conditions (aqueous acidity and organic octanol concentration) were changed through time $(N E=1)$, the measured variable was the organic acid concentration $\left(N V_{l}=1\right)$ and the number of measurements was taken to be the number of datapoints included in fitting $\left(N M_{11}=53\right)$.

An initial estimation run was undertaken to establish a suitable expression for the activity coefficient. This gave values for constants $\mathrm{A}$ through $\mathrm{E}$ as shown in Table 1 giving the expression for activity shown in Equation 10 which was used for all subsequent fitting. The expression for activity was then fixed and the estimation rerun, yielding the stability constants given in Table 1.

Table 1: Fitted coefficients for correlation (equations 4 and 6) to calculate nitric acid distribution into kerosene-octanol mixtures.

\begin{tabular}{|c|c|c|c|c|c|c|c|}
\hline$A$ & $B$ & $C$ & $D$ & $E$ & $\beta_{11}$ & $\beta_{12}$ & $\beta_{13}$ \\
\hline 0.1080 & 0.5962 & 0.6100 & 0.1131 & -0.002716 & 0.006101 & 0.001585 & 0.0003546 \\
\hline
\end{tabular}

From this it is found that the expression for nitric acid distribution is given by Equation 9 where [Oct] is the free octanol concentration, $\left[\mathrm{HNO}_{3}\right]$ is the total (stoichiometric) nitric acid concentration and $\gamma_{\mathrm{s}}$ is given by Equation 10 .

$$
D_{\mathrm{HNO}_{3}}=\gamma_{s}^{2}\left[\mathrm{HNO}_{3}\right]\left(0.006101[\mathrm{Oct}]+0.001585[\mathrm{Oct}]^{2}+0.0003546[\mathrm{Oct}]^{3} \quad \text { (Equation } 9\right.
$$




$$
\gamma_{s}=\left[\frac{0.108}{\left(0.5962+\left[\mathrm{HNO}_{3}\right]\right)^{2}}+0.61+0.1131\left[\mathrm{HNO}_{3}\right]-0.002716\left[\mathrm{HNO}_{3}\right]^{2}\right]
$$

Statistical measures of the fit are given in Table 2 below.

Table 2: Quality of fit for model of $\mathrm{HNO}_{3}$ extraction into octanol / TPH.

\begin{tabular}{|c|c|c|c|}
\hline \multicolumn{2}{|c|}{ Variance model (see Equation 7) } & \multicolumn{2}{|c|}{$\chi^{2}$-test } \\
\hline$\omega$ & $\gamma$ & $\chi^{2}$ & $\chi^{2}$-critical \\
\hline 0.00744 & 0.724 & 53.00 & 65.17 \\
\hline
\end{tabular}

The value of gamma indicates that errors are predominantly related to the magnitude of the measurement being made whilst the $\chi^{2}$ value being less than the $\chi^{2}$-critical value indicates that the null hypothesis (that the difference between the weighted residual and the and expected weighted residual is zero) cannot be rejected at the $95 \%$ confidence level, thereby indicating a good fit.

Plots of model predictions vs. experimental results (from reference $\left[{ }^{37}\right]$ ) are shown in Figure 2. Percentage errors across the range of the experiments are rather small. For aqueous phase nitric acid concentrations in excess of $1.5 \mathrm{~mol} / \mathrm{L}$, the model gives predictions with root mean square (rms) error of $1.5 \%$ whilst at acidities below $1.5 \mathrm{~mol} / \mathrm{L}$ the rms error is $5.1 \%$. This model shows slightly improved accuracy over the one reported in reference $\left[{ }^{37}\right]$, most notably at aqueous nitric acid concentrations beyond $1 \mathrm{~mol} / \mathrm{L}$.

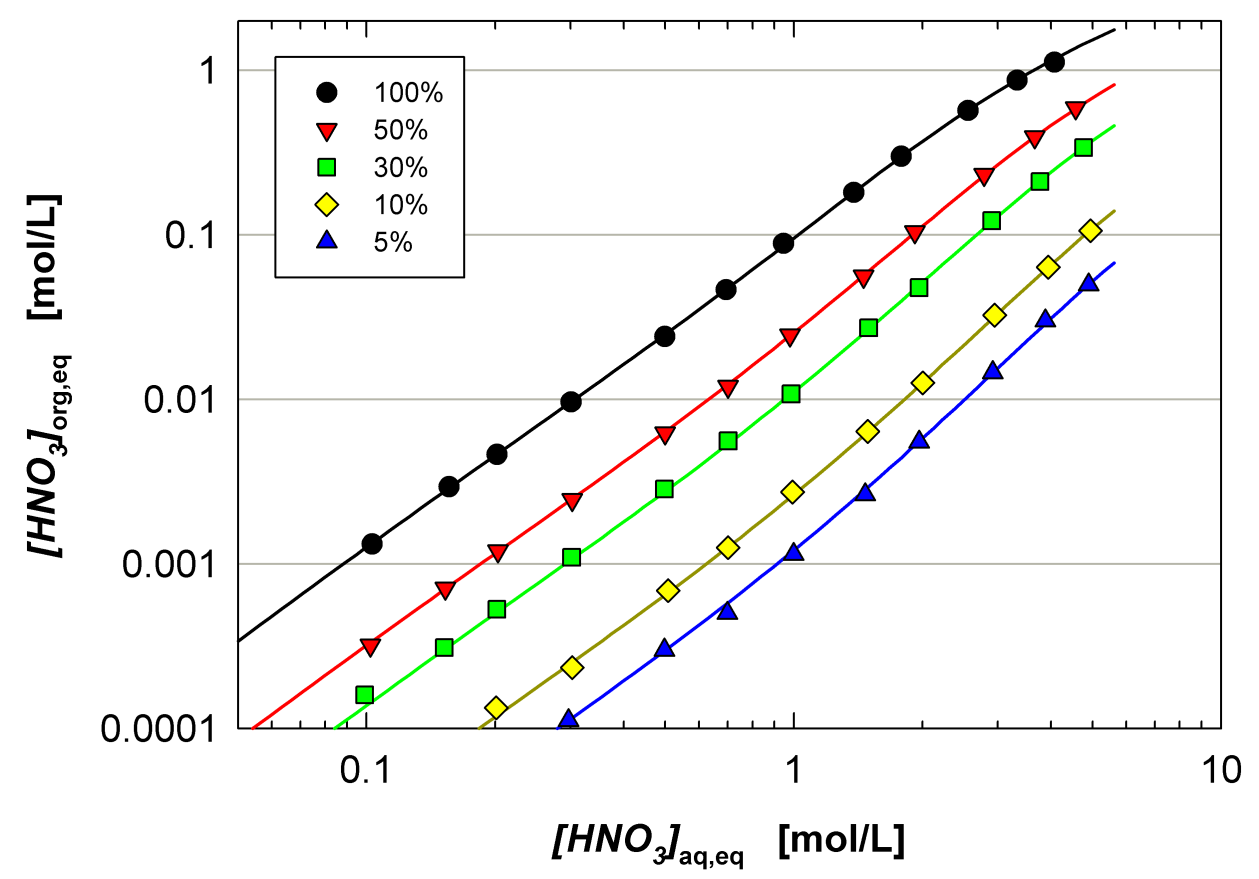

Figure 2: Extraction of nitric acid into octanol-TPH mixtures (octanol volume fraction as indicated); model predictions (lines) vs. experimental data (symbols). $A / O=1, T=(20 \pm$ $0.5){ }^{\circ} \mathrm{C}$. Experimental data from reference $\left[{ }^{37}\right]$. See Table SI 1 for experimental data. 


\section{Extraction of Nitric Acid into TODGA}

The extraction of nitric acid into TODGA solvents was determined for the following experimental conditions, $0.05-0.4 \mathrm{~mol} / \mathrm{L}$ TODGA, 0.1-8.7 mol/ $\mathrm{LNO}_{3}$, diluent was Exxsol D80. Temperature was $20 \pm 0.5^{\circ} \mathrm{C}, 22 \pm 1{ }^{\circ} \mathrm{C}$ or ambient $\left(\approx 20-25^{\circ} \mathrm{C}\right)$, depending on which of the labs involved performed the experiments.

Experimental data for the extraction of nitric acid into TODGA in Exxsol D80 are compared to calculated values (see below) in Figure 3. A number of points are apparent from initial inspection of the experimental data:

- A series of datapoints at a TODGA concentration of $0.2 \mathrm{~mol} / \mathrm{L}$ is somewhat inconsistent with the remaining data, generally showing around $0.05 \mathrm{~mol} / \mathrm{L}$ more nitric acid being extracted into the solvent than the other data sets give for similar conditions.

- Organic phase acidity up to 2.5 times the TODGA concentration is observed at the highest nitric acid concentrations considered. This implies that adducts with at least a 3:1 nitric acid:TODGA ratio must be present.

- Distribution ratios show a roughly linear dependence on TODGA concentration for a given acidity. This suggests that the solvent phase adducts of the form $n \mathrm{HNO}_{3} \cdot$ TODGA are dominating.

- Distribution ratios for nitric acid show little dependence on acidity at moderate and high acidities. For $0.1 \mathrm{~mol} / \mathrm{L}$ TODGA, $\mathrm{D}\left(\mathrm{HNO}_{3}\right)$ is around 0.033 for greater than $2 \mathrm{~mol} / \mathrm{L}$ nitric acid. With $0.2 \mathrm{~mol} / \mathrm{L}$ TODGA, $\mathrm{D}\left(\mathrm{HNO}_{3}\right)$ is around 0.06 to 0.07 for $\left[\mathrm{HNO}_{3}\right]>0.5 \mathrm{~mol} / \mathrm{L}$ and with $0.3 \mathrm{~mol} / \mathrm{L}$ TODGA, $D\left(\mathrm{HNO}_{3}\right)$ is around 0.1 to 0.12 for $\left[\mathrm{HNO}_{3}\right]>1 \mathrm{~mol} / \mathrm{L}$. This behaviour is slightly unexpected as typical extraction behaviour would have distribution ratios initially increasing with acidity then decreasing at higher acidity as solvent saturation effects cut in. 


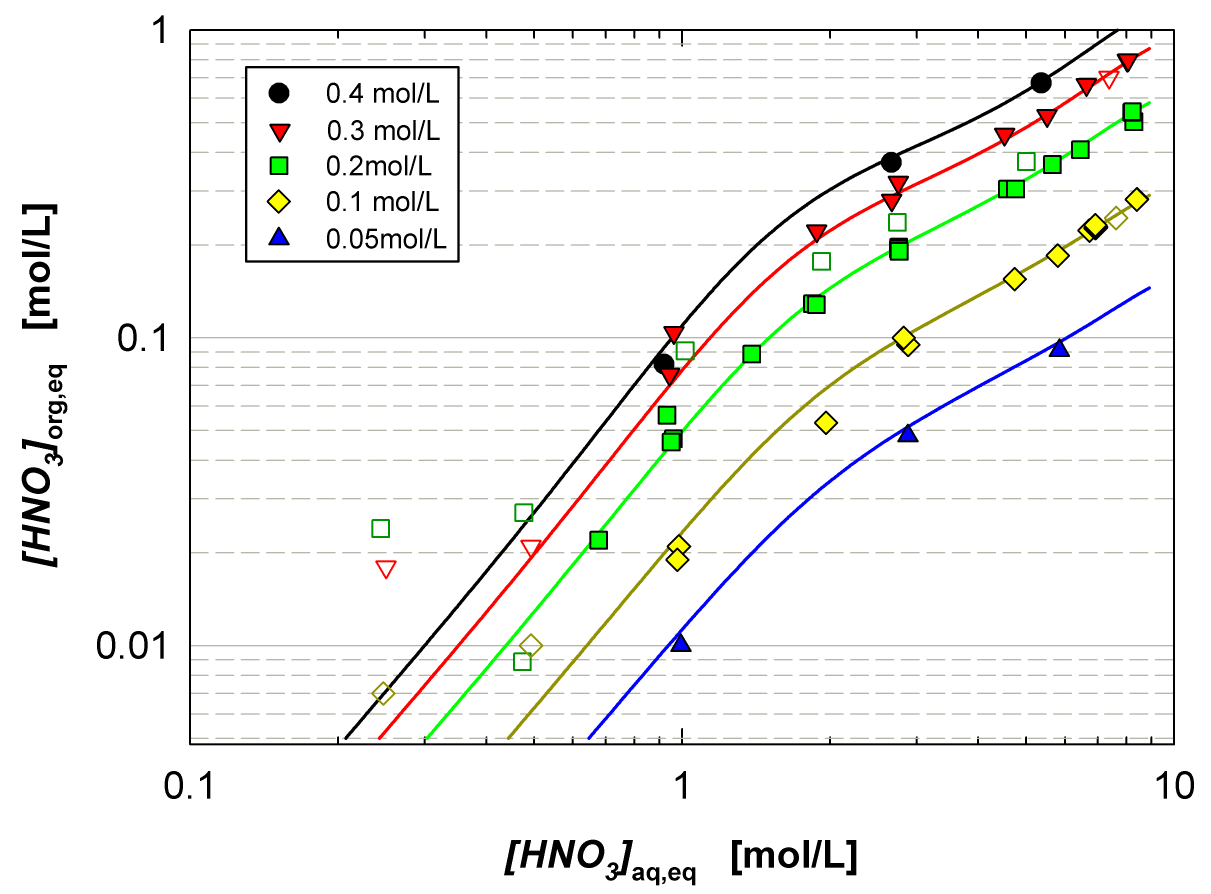

Figure 3: Nitric acid extraction into TODGA (concentration as indicated) in Exxsol D80. Model predictions (lines) vs. experimental data (symbols; open symbols excluded from fitting). $A / O=1$. See Table SI 2 for experimental data.

Fitting of the experimental data has been undertaken in the same ways as for the extraction of nitric acid into octanol, assuming that the solvent phase contains adducts of the form $i \mathrm{HNO}_{3} \cdot j$ TODGA so that the nitric acid concentration is described by Equation 11.

$$
\left[\mathrm{HNO}_{3}\right]_{(\mathrm{org})}=\sum_{i=1}^{n} \sum_{j=1}^{m} i \beta_{i j} \gamma_{s}^{2 i}\left[\mathrm{HNO}_{3}\right]_{(a q)}^{2 i}[\mathrm{TODGA}]^{j}
$$

In this equation [TODGA] is the free TODGA which is determined by use of a continuity equation analogous to that used for octanol (Equation 5). The fitting allowed adducts ranging from $4 \mathrm{HNO}_{3}$. TODGA through to $\mathrm{HNO}_{3}$.TODGA and $\mathrm{HNO}_{3} \cdot 2 \mathrm{TODGA}$ through to $\mathrm{HNO}_{3} \cdot 4 \mathrm{TODGA}$. Additionally, the $2 \mathrm{HNO}_{3} \cdot 2 \mathrm{TODGA}$ adduct was allowed as were the TODGA oligomers 2TODGA, through to 4TODGA. Only the stability constants were fitted, the expression for $\gamma_{\mathrm{s}}$ derived in the fitting of octanol extraction being used here as well. Again, fitting was achieved by minimising the objective function given in Equation 8. Data at less than $0.5 \mathrm{~mol} / \mathrm{L}$ aqueous acidity was omitted from the fitting in light of the scatter observed in the data in this region and the low amounts of extracted acid involved that will normally result in flow-sheet model predictions having a low sensitivity to relative errors in acid distribution values at low acidity. The outlying data (series 3, open triangles in Figure 3) was excluded from the fitting process due to the offset observed between it and the other data sets. Of the adducts allowed, initial fitting set stability constants for $\mathrm{HNO}_{3}$.3TODGA, $\mathrm{HNO}_{3} \cdot 4 \mathrm{TODGA}, 2 \mathrm{TODGA}$, and 3TODGA to zero. Although the best fit was obtained when $\mathrm{HNO}_{3} \cdot 2$ TODGA and 4TODGA species had non-zero stability constants, the $95 \%$ confidence limits for the predicted values took in zero and it was found that there was very little loss in 
model accuracy if these species were omitted. For the remaining adducts the fitting process resulted in stability constants as in Table 3 below:

Table 3: Fitted constants for nitric acid distribution into TODGA $(0.1-0.3 \mathrm{~mol} / \mathrm{L})$ in Exxsol D80.

\begin{tabular}{|c|c|c|c|c|}
\hline$\beta_{41}$ & $\beta_{31}$ & $\beta_{21}$ & $\beta_{11}$ & $\beta_{22}$ \\
\hline $9.056 \mathrm{E}-7$ & $9.009 \mathrm{E}-5$ & 0.02193 & 0.4482 & 0.4987 \\
\hline
\end{tabular}

These constants differ from those reported in a previous study $\left[{ }^{24}\right]$. The differences are explained by the use of different activity models and the use of the $2 \mathrm{HNO}_{3} \cdot 2$ TODGA adduct instead of the $\mathrm{HNO}_{3} \cdot 2 \mathrm{TODGA}$ adduct.

Statistical measures of the fit are given in Table 4 below.

Table 4: Quality of fit for model of $\mathrm{HNO}_{3}$ distribution into TODGA in Exxsol D80.

\begin{tabular}{|c|c|c|c|}
\hline \multicolumn{2}{|c|}{ Variance model (see Equation 7) } & \multicolumn{2}{|c|}{$\chi^{2}$-test } \\
\hline$\omega$ & $\gamma$ & $\chi^{2}$ & $\chi^{2}$-critical \\
\hline 0.01609 & 0.2701 & 58.00 & 68.67 \\
\hline
\end{tabular}

Figure 3 shows a comparison of the model results against the available experimental data. Root mean square error for the fitted data is $9.9 \%$ overall $\left(17 \%\right.$ for $\left[\mathrm{HNO}_{3}\right]_{(\mathrm{aq})}<1.5 \mathrm{~mol} / \mathrm{L}$, $5.6 \%$ for $\left.\left[\mathrm{HNO}_{3}\right]_{(\mathrm{aq})}>1.5 \mathrm{~mol} / \mathrm{L}\right)$ The wide scatter of data at low acidity is apparent, making a close fit to data in this region impossible. Despite potentially high relative errors in the calculation of organic phase nitric acid concentration under conditions of low aqueous phase nitric acid concentrations, absolute errors remain small so that models of typical flow-sheets should not be greatly affected by sensitivity to nitric acid distribution at low acidity

\section{Extraction of Nitric Acid into TODGA-Octanol Solvents}

Data sets for the extraction of acid into combined TODGA/octanol solvents have been generated for varied experimental conditions, $0.05-0.3 \mathrm{~mol} / \mathrm{L}$ TODGA, $5 \mathrm{v} / \mathrm{v} \%$ octanol, $0.1-$ $6 \mathrm{~mol} / \mathrm{L} \mathrm{HNO}_{3}$ and $0.1-0.3 \mathrm{~mol} / \mathrm{L}$ TODGA, 5-50\% v/v\% octanol, $\approx 2.8 \mathrm{~mol} / \mathrm{L} \mathrm{HNO}_{3}$. Diluent was Exxsol D80 or TPH (it was verified that the diluent does not have any effect on the quantity of nitric acid extracted, see Supporting Information, "diluent effect on nitric acid extraction"). Temperature was $20 \pm 0.5^{\circ} \mathrm{C}, 22 \pm 1{ }^{\circ} \mathrm{C}$ or ambient $\left(\approx 20-25^{\circ} \mathrm{C}\right)$, depending on which of the labs involved performed the experiments. However, the temperature effect on nitric acid extraction is moderate (see below).

Following exclusion of obvious outliers, experimental data from different laboratories typically agreed well. Results are shown in Figure 4. 


\section{Performance of Correlations Neglecting Synergistic Effects}

Initial calculations were undertaken in which the solvent phase nitric acid concentration was modelled as the sum of the predicted nitric acid extraction into TODGA plus that resulting from nitric acid extraction into octanol. Figure 4 shows predicted vs. measured organic nitric acid concentrations for experimental series at $0.05,0.1,0.2$ and $0.3 \mathrm{~mol} / \mathrm{L}$ TODGA, respectively.

General trends are apparent. For nitric acid concentrations above about $1.5 \mathrm{~mol} / \mathrm{L} \mathrm{HNO}_{3}$, the superposition of the TODGA and octanol models results in under prediction of extracted nitric acid, typically by approximately $10 \%$. In the region $0.5-1.5 \mathrm{~mol} / \mathrm{L}$ nitric acid, the model over predicts nitric acid extraction by up to $40 \%$, the over prediction being largest at lower acidity. For acidities less than $0.6 \mathrm{~mol} / \mathrm{L}$, the data are too scattered to allow any general trends to be discerned.

The antagonistic behaviour observed at low acidity could be caused by association of TODGA with octanol resulting in a reduction in the availability of both TODGA and octanol for extraction of nitric acid. Synergistic behaviour observed at higher acidities is potentially a consequence of the formation of adducts containing nitric acid, TODGA and octanol in some ratio.

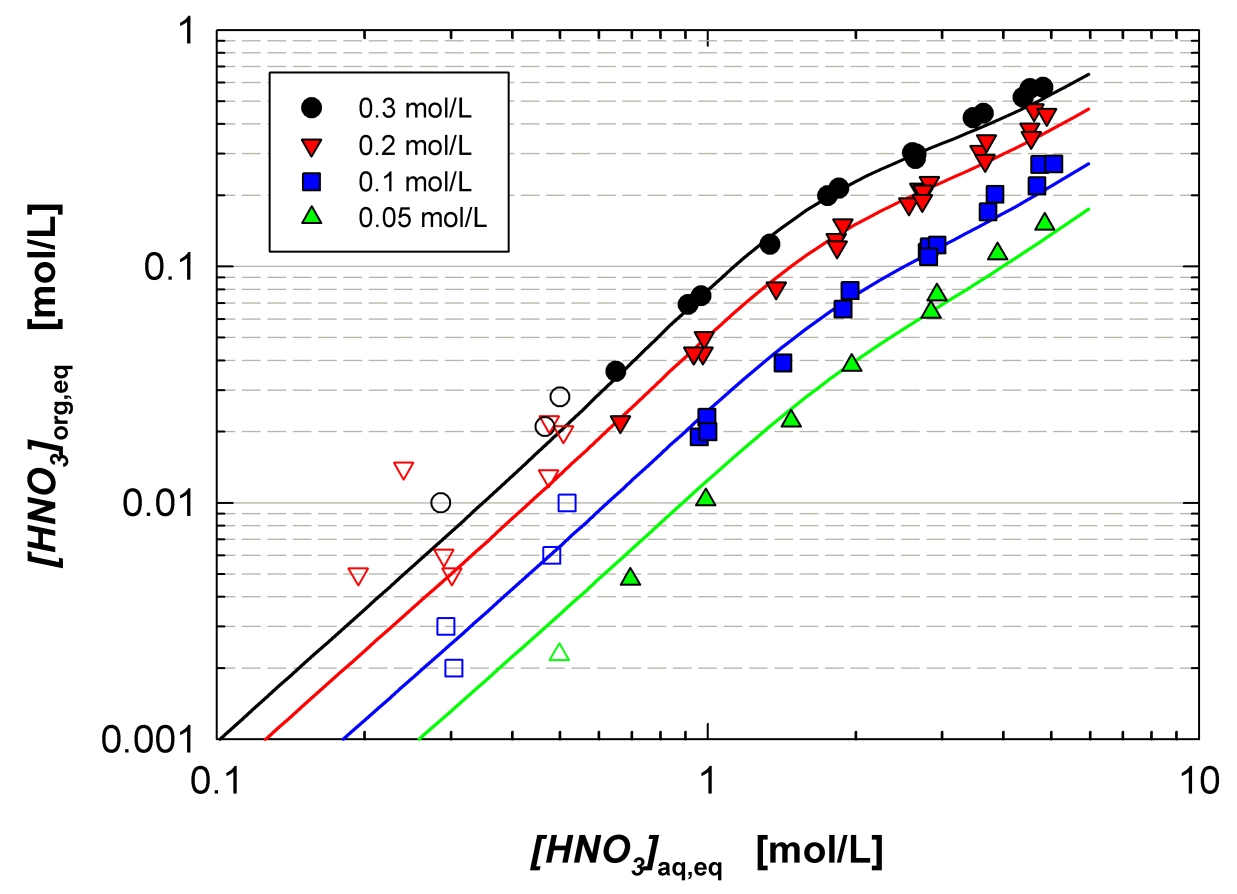

Figure 4: Nitric acid extraction into TODGA (concentration as indicated) $+5 \mathrm{v} / \mathrm{v} \%$ octanol in Exxsol D80 or TPH. Symbols, experiments (open symbols excluded from fitting). Lines, calculated by superposition of models for nitric acid extraction into octanol and nitric acid extraction into TODGA. $A / O=1$. See Table SI 3 for experimental data. 


\section{Inclusion of Synergistic Extraction of Acid by TODGA-Octanol Mixtures.}

In light of the results above, the additive model for extraction of acid into TODGA-octanol mixtures was extended by the inclusion of a range of adducts containing both TODGA and octanol. Initial runs allowed a range of adducts of the form $i \mathrm{HNO}_{3} \cdot j \mathrm{TODGA} \cdot k$ Octanol $((i, j$, $k)=(0,1,1),(0,1,2),(0,1,3),(0,1,4),(0,2,1),(0,3,1),(0,4,1),(1,1,1),(1,1,2),(1,1$, $3),(1,1,4),(2,1,1),(2,1,2),(2,1,3)(3,1,1),(3,1,2),(4,1,1))$. gPROMS parameter estimation was used to estimate the stability constants of these species, only data corresponding to greater than $0.6 \mathrm{~mol} / \mathrm{L} \mathrm{HNO}_{3}(\mathrm{aq})$ being used due to scatter of data measured at lower acidity. Of these adducts only nine $((i, j, k)=(0,1,2),(0,1,4),(1,1,1),(1,1,2),(2$, $1,1),(2,1,2),(2,1,3),(3,1,2),(4,1,1))$ were predicted to have non-zero stability constants. Of these nine potential adducts five could be eliminated with minimal effect on the observed residuals leaving $((i, j, k)=(0,1,2),(1,1,1),(2,1,3),(3,1,2))$. Adducts were chosen for elimination based on the $95 \%$ confidence limits for the stability constants calculated by gPROMS taking in zero. Root mean square errors for the model with all adducts considered was $5.66 \%$ compared to $6.02 \%$ with only 4 TODGA octanol cross adducts being considered. The fitted stability constants are presented in Table 5 below.

Table 5: Fitted equilibrium constants for $\mathrm{HNO}_{3}$-TODGA-octanol adducts.

\begin{tabular}{|c|c|c|c|}
\hline $\begin{array}{c}\text { TODGA } 2 \mathrm{Oct} \\
\beta_{012}\end{array}$ & $\begin{array}{c}\mathrm{HNO}_{3} \cdot \mathrm{TODGA} \cdot \mathrm{Oct} \\
\beta_{111}\end{array}$ & $\begin{array}{c}2 \mathrm{HNO}_{3} \cdot \mathrm{TODGA} \cdot 3 \mathrm{Oct} \\
\beta_{213}\end{array}$ & $\begin{array}{c}3 \mathrm{HNO}_{3} \cdot \mathrm{TODGA} \cdot 2 \mathrm{Oct} \\
\beta_{312}\end{array}$ \\
\hline 27.47 & 2.419 & 0.7328 & 0.06431 \\
\hline
\end{tabular}

Statistical measures of the fit are given in Table 6 below.

Table 6: Quality of fit for model of $\mathrm{HNO}_{3}$ distribution into TODGA / octanol / diluent.

\begin{tabular}{|c|c|c|c|}
\hline \multicolumn{2}{|c|}{ Variance model (see Equation 7) } & \multicolumn{2}{|c|}{$\chi^{2}$-test } \\
\hline$\omega$ & $\gamma$ & $\chi^{2}$ & $\chi^{2}$-critical \\
\hline 0.0556 & 0.959 & 83.02 & 98.48 \\
\hline
\end{tabular}

The organic phase nitric acid in the improved model is calculated by Equation 12 below where the TODGA and octanol concentrations are the concentration of free TODGA and octanol.

$$
\left[\mathrm{HNO}_{3}\right]_{(\mathrm{org})}=\sum_{i=1}^{n} \sum_{j=0}^{m} \sum_{k=0}^{p} i \beta_{i j k} \gamma_{s}^{2 i}\left[\mathrm{HNO}_{3}\right]_{(\text {aq })}^{2 i}[\mathrm{TODGA}]^{j}[\text { Octanol }]^{k} \quad \text { (Equation } 12 \text { ) }
$$

The continuity equations for TODGA and octanol are updated in the obvious manner to take account of the cross adducts. Results for the updated model are shown in Figure 5. Comparison to Figure 4 (i.e. the system not including the cross adducts) shows that the over prediction in acidity range $0.5-1.5 \mathrm{~mol} / \mathrm{L}$ and the tendency to under predict at higher acidity are both largely eliminated. 


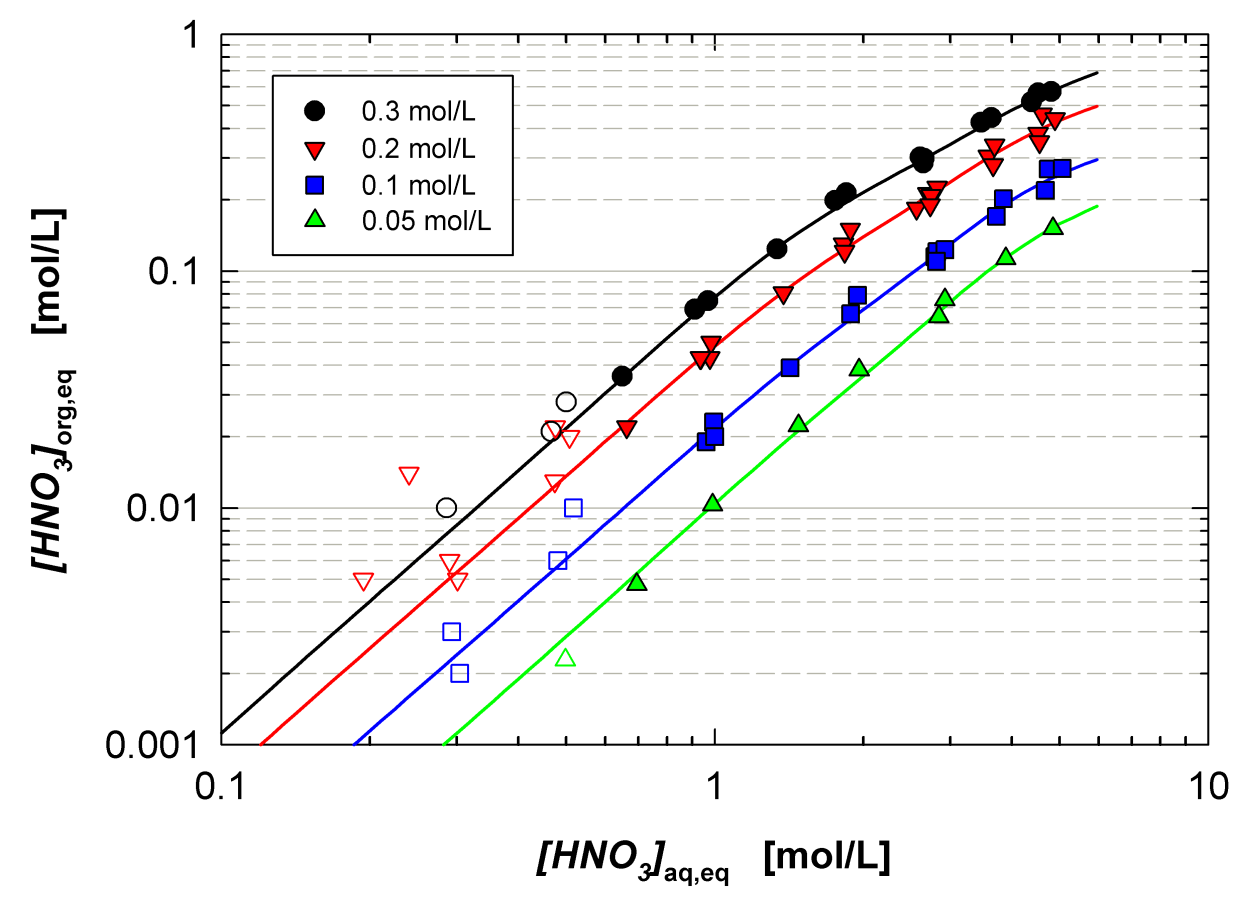

Figure 5: Nitric acid extraction into TODGA (concentration as indicated) $+5 \mathrm{v} / \mathrm{v} \%$ octanol in Exxsol D80 or TPH. Symbols, experiments (open symbols excluded from fitting). Lines, calculated by the improved model accounting for synergistic adducts. $A / O=1$. See Table SI 3 for experimental data.

The range of adducts considered allows a good fit to the available data to be achieved, with Figure 5 showing no clear trends in residual errors that would suggest the possibility of a significantly better model being found. The situation at the lowest acidities remains uncertain due to scatter in the data. However, the absolute deviations are on the order of few $\mathrm{mmol} / \mathrm{L}$.

The work reported here has considered a wide but not comprehensive range of cross adducts and narrowed down the list to those required to give a good fit to the available data. However, there is no guarantee that these adducts are present in reality or that there are no other adducts present. Further refinement of the correlations is, however, unlikely to be feasible without substantial expansion of the dataset.

\section{Predicted Prevalence of Different Adducts in Extracted Nitric Acid}

In order to give an indication of the relative importance of the different adducts, the concentrations of individual species expressed as a percentage of the extracted nitric acid were calculated for a number of representative cases. These are shown in Tables SI 5-7 (see Supporting Information) which present predicted solvent phase composition given by the model with inclusion of cross adducts. For the particular case of $0.2 \mathrm{~mol} / \mathrm{L}$ TODGA $+5 \mathrm{v} / \mathrm{v} \%$ octanol in an inert diluent, i.e. the solvent used in the i-SANEX flowsheet $\left[{ }^{14}\right]$, the predicted speciation diagrams for solvent phase nitric acid, octanol and TODGA as a function of aqueous phase acidity are shown in Figure 6, Figure 7 and Figure 8, respectively. A number of points are apparent from these tables and figures: 
- A large fraction of the octanol remains unbound in all cases.

- Extraction of nitric acid into TODGA is generally greater than into octanol, except when high octanol concentrations are used. Even in this case much of the nitric acid is extracted as a cross adduct rather than as a pure TODGA or octanol adduct.

- The $4 \mathrm{HNO}_{3} \cdot \mathrm{TODGA}$ adduct is significant only at the highest acidity considered.

- The $\mathrm{HNO}_{3} \cdot 2 \mathrm{Octanol}$ and $\mathrm{HNO}_{3} \cdot 3$ Octanol adducts are only significant when the octanol concentration is well above the $5 \mathrm{v} / \mathrm{v} \%$ expected to be used in practice.

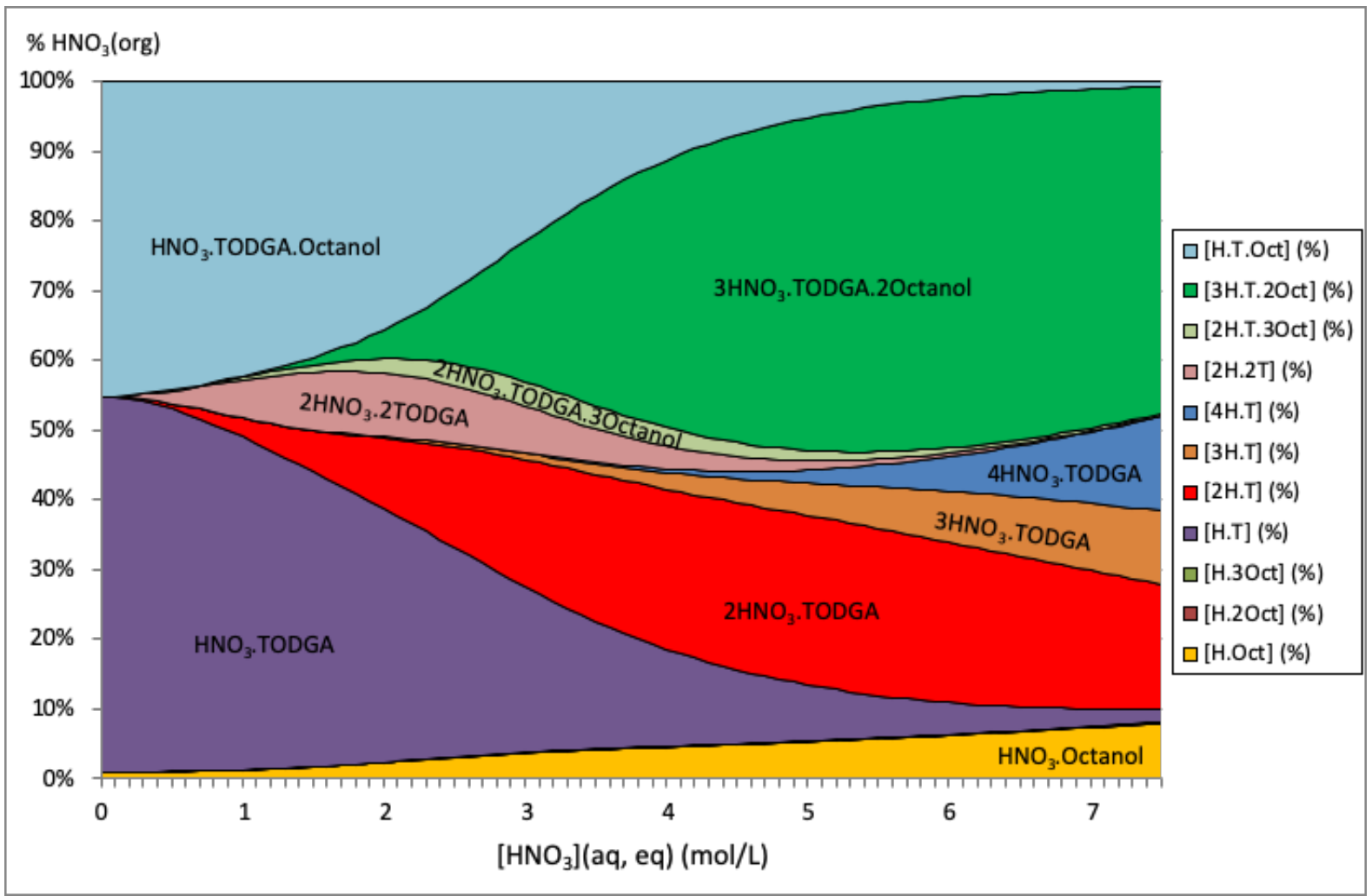

Figure 6: Predicted organic nitric acid speciation in a $0.2 \mathrm{~mol} / \mathrm{L}$ TODGA $+5 \mathrm{v} / \mathrm{v} \%$ octanol system. 


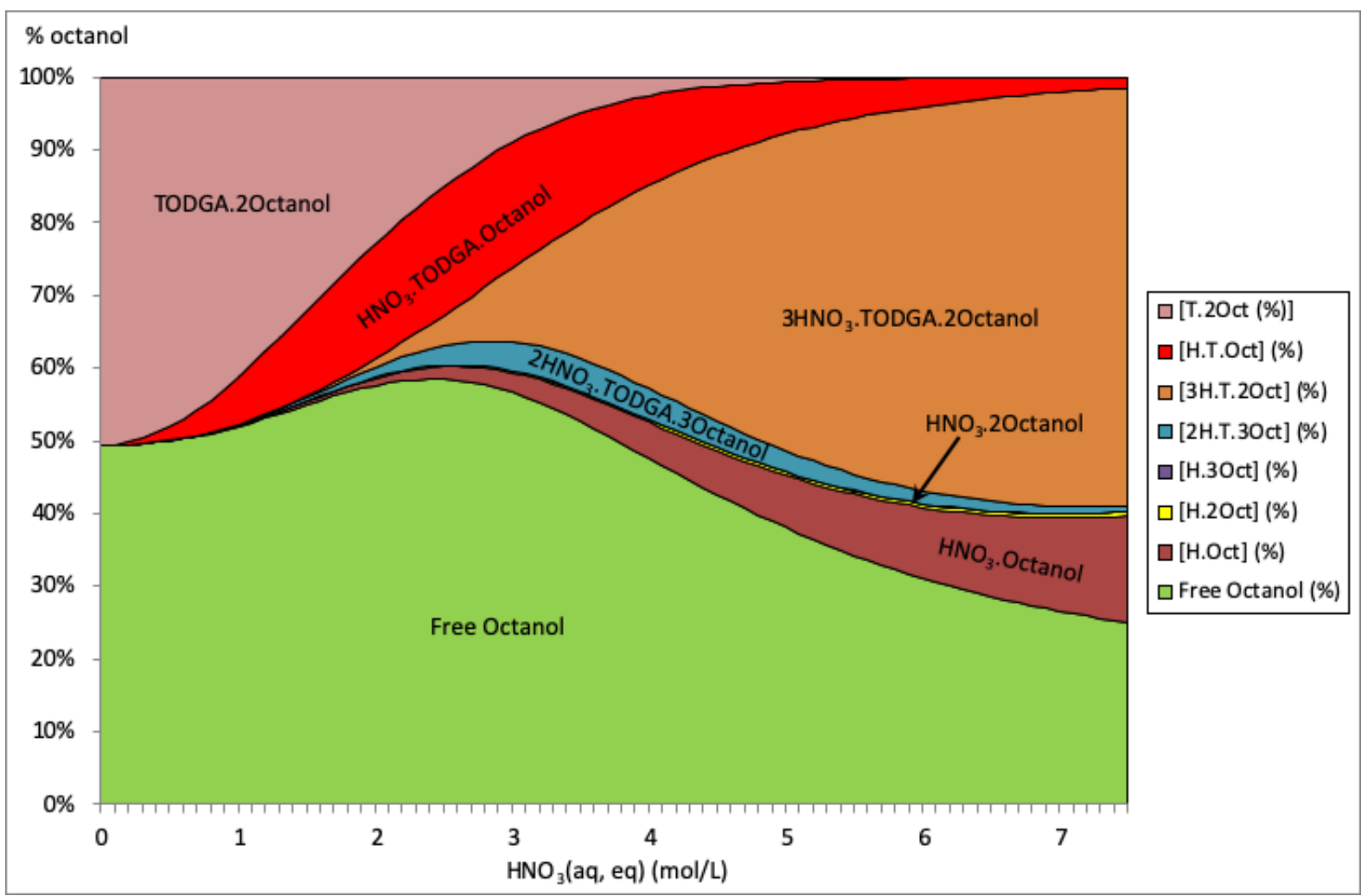

Figure 7: Predicted octanol speciation in a $0.2 \mathrm{~mol} / \mathrm{L}$ TODGA $+5 \mathrm{v} / \mathrm{v} \%$ octanol system.

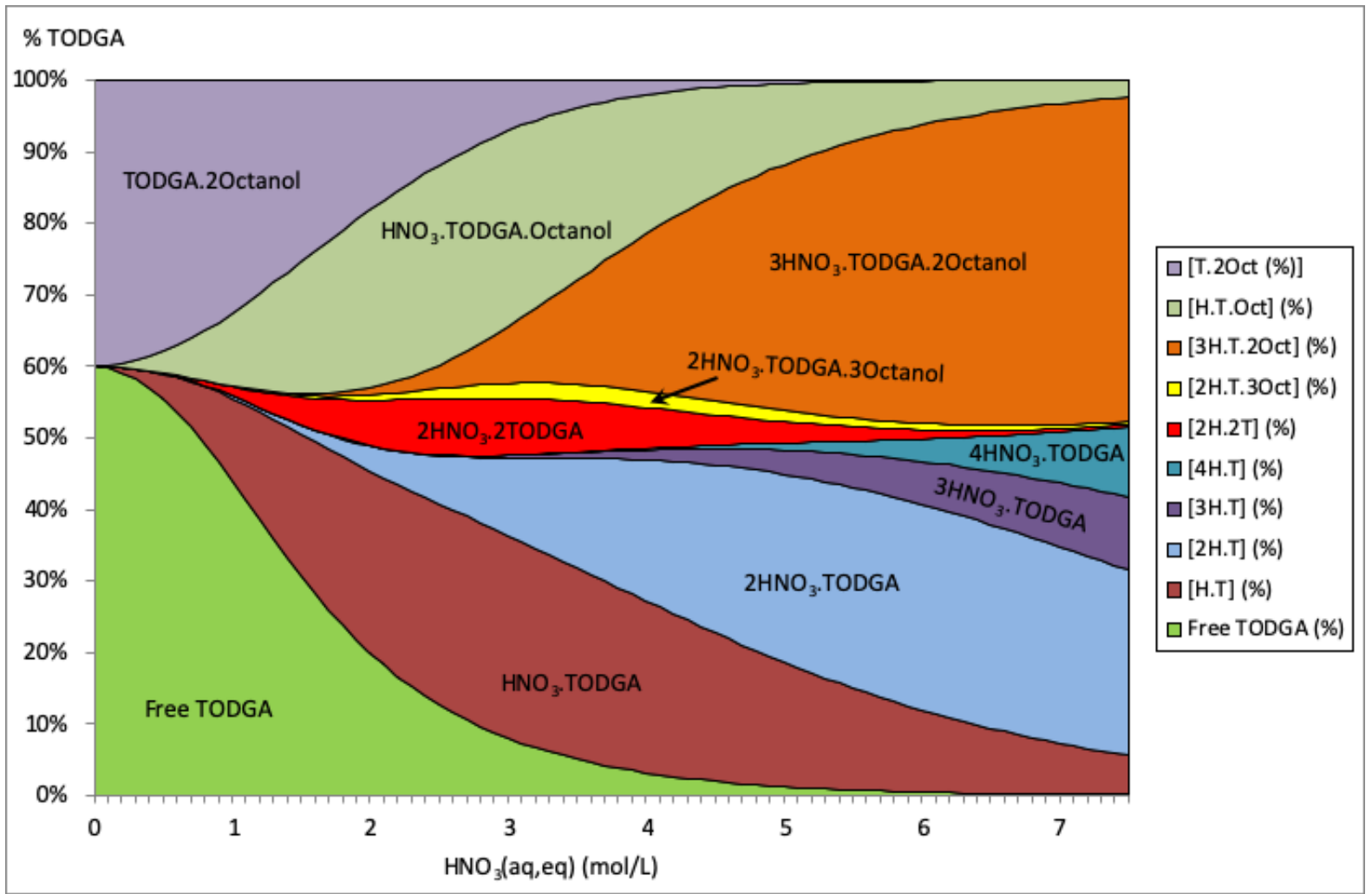

Figure 8: Predicted TODGA speciation in a $0.2 \mathrm{~mol} / \mathrm{L}$ TODGA $+5 \mathrm{v} / \mathrm{v} \%$ octanol system. 


\section{Temperature Effects}

Data for the extraction of nitric acid into mixtures of TODGA and octanol as a function of temperature were determined for the following experimental conditions, $0.1-0.2 \mathrm{~mol} / \mathrm{L}$ TODGA, 5\% v/v octanol, $0.31-3.1 \mathrm{~mol} / \mathrm{L} \mathrm{HNO}_{3}, 10-50{ }^{\circ} \mathrm{C}$.

In order to incorporate temperature effects into the model it is assumed that the stability constants for the solvent phase adducts have an Arrhenius type dependence on temperature resulting in calculation of organic phase acid by Equation 13 below.

$$
\left[\mathrm{HNO}_{3}\right]_{(\mathrm{org})}=\sum_{i=1}^{n} \sum_{j=0}^{m} \sum_{k=0}^{p} i A_{i j k} e^{\left(-\frac{E_{i j k}}{R T}\right)} \beta_{i j k} \gamma_{s}^{2 i}\left[\mathrm{HNO}_{3}\right]_{(a q)}^{2 i}[T O D G A]^{j}[O c t a n o l]^{k} \quad \text { (Equation } 13 \text { ) }
$$

In the above equation $T$ is the temperature in Kelvin and $R$ is the universal gas constant. $A_{i j k}$ and $E_{i j k}$ are fitted constants with the $E_{\mathrm{ijk}}$ taking a role analogous to the Gibbs free energies $\left(\Delta G^{0}\right)$ for the adducts $\left(\mathrm{HNO}_{3}\right)_{i} \cdot \mathrm{TODGA}_{j} \cdot \mathrm{Octanol}_{k}$. They cannot be considered to be true $\Delta G^{0}$ for the adducts because the actual adducts are likely to contain water as well as the modelled solvent phase species. The above general form is impractical for use in models due to the requirement to provide fitted constants for each of the postulated solvent phase adducts, the available data being too limited to allow the necessary deconvolution. The more practical approach is then to assume that a single value of $E$ applies for all the adducts so that Equation 14 below applies.

$$
\left.\left[\mathrm{HNO}_{3}\right]_{(\mathrm{org})}=\sum_{i=1}^{n} \sum_{j=0}^{m} \sum_{k=0}^{p} i A_{i j k} e^{\left(-\frac{E}{R T}\right)} \beta_{i j k} \gamma_{s}^{2 i}\left[\mathrm{HNO}_{3}\right]_{(a q)}^{2 i}[\text { TODGA }]^{j}[\text { Octanol }]^{k} \quad \text { (Equation } 14\right)
$$

In effect, a temperature correction factor, $K$, is applied to the existing model, this being given by:

$$
K=A e^{\left(-\frac{E}{R T}\right)}
$$

(Equation 15 )

Fitting is further constrained by the requirement for consistency with the model (and hence underpinning data) obtained at ambient temperature. For this reason a constraint was applied to the fitting such that $K$ takes a value of 1 at $20{ }^{\circ} \mathrm{C}$. As with fitting of other data for extraction of acid into TODGA containing solvents, the fit did not include points where the aqueous acidity was less than $0.6 \mathrm{~mol} / \mathrm{L}$. When this is done we obtain $E=-25.7 \mathrm{~kJ} / \mathrm{mol}, A=$ $2.580 \mathrm{E}-5$.

Statistical measures of the fit are given in Table 7 below.

Table 7 : Quality of fit for model of $\mathrm{HNO}_{3}$ distribution into TODGA / octanol / diluent with temperature dependence.

\begin{tabular}{|c|c|c|c|}
\hline \multicolumn{2}{|c|}{ Variance model (see Equation 7) } & \multicolumn{2}{|c|}{$\chi^{2}$-test } \\
\hline$\omega$ & $\gamma$ & $\chi^{2}$ & $\chi^{2}$-critical \\
\hline 0.0293 & 0.8435 & 24.00 & 32.67 \\
\hline
\end{tabular}


Fits of the data in Table SI 4 (see Supporting Information) against the model with the temperature correction are shown in Figure 9 below.

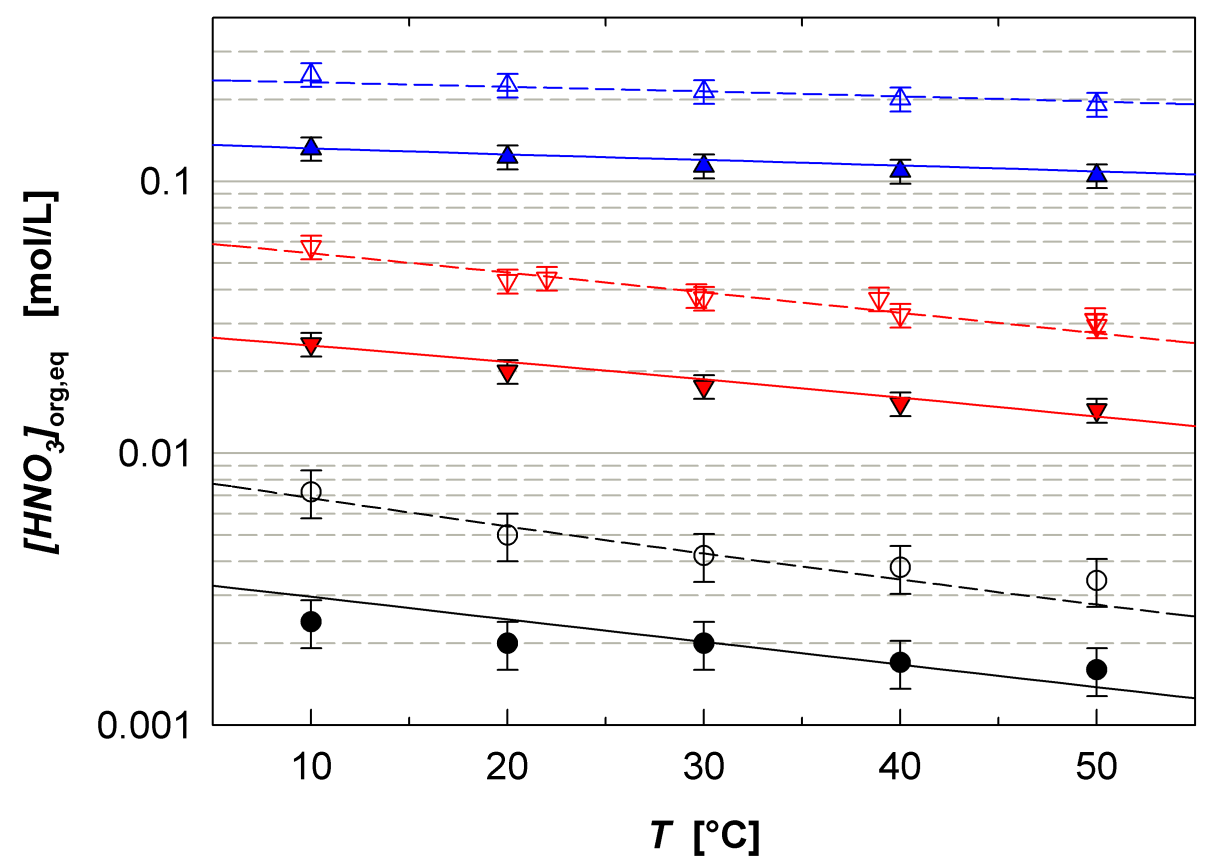

Figure 9: Temperature dependent nitric acid extraction. Organic phase, $0.1 \mathrm{~mol} / \mathrm{L}$ (solid symbols and lines) or $0.2 \mathrm{~mol} / \mathrm{L}$ (open symbols, dashed lines) TODGA $+5 \mathrm{v} / \mathrm{v} \%$ octanol in TPH. Aqueous phase, initial $\mathrm{HNO}_{3}(\mathbf{0 . 3 0 6}-\mathbf{1 . 0 2}-\mathbf{3 . 0 5} \mathrm{mol} / \mathrm{L}) . A / O=1$. Lines, model: $E=$ $-25.7 \mathrm{~kJ} / \mathrm{mol}, A=2.580 \mathrm{E}-5$. Experimental uncertainty estimated to $5 \%\left(\left[\mathrm{HNO}_{3}\right]_{\text {org,eq }} \geq\right.$ $10 \mathrm{mmol} / \mathrm{L})$ and $20 \%\left(\left[\mathrm{HNO}_{3}\right]_{\mathrm{org}, \mathrm{eq}}<10 \mathrm{mmol} / \mathrm{L}\right)$

Figure 9 shows a good model fit to data at nitric acid concentrations of 1.0 and $3.1 \mathrm{~mol} / \mathrm{L}$ with a less good fit at lower acidity, particularly at the lower TODGA concentration. This once again reflects the wider scatter of the data at low acidity. Absolute organic acid concentrations are always very low in this region and although relative errors are substantial, absolute model errors are less than $1 \mathrm{mmol} / \mathrm{L}$ which is of little concern in most practical modelling applications.

\section{Model Applicability and Limitations}

The work reported in this paper has resulted in the production of a model of nitric acid extraction into mixtures of TODGA and octanol with an essentially inert kerosene diluent. The model has an underlying framework rooted in the theory of solvent extraction, but includes a significant element of empirical modification to take account of the unknown parameters in the system. The empirical component will limit the extent to which the model can be reliably applied to conditions beyond those used to fit the model. In general, these give coverage for $0.05-0.3 \mathrm{~mol} / \mathrm{L}$ TODGA, 5-50 v/v\% octanol, $0-5 \mathrm{~mol} / \mathrm{L} \mathrm{HNO}_{3}$ and $10-50{ }^{\circ} \mathrm{C}$, although a few data points outside of these ranges have also been used in fitting of the models. Not all combinations of data within these ranges have considered, with the largest 
amounts of data relating to extraction into $0.2 \mathrm{~mol} / \mathrm{L}$ TODGA with $5 \mathrm{v} / \mathrm{v} \%$ octanol at ambient temperature. Notably temperature dependent data relates only to systems containing $5 \mathrm{v} / \mathrm{v} \%$ octanol, leaving the possibility that high octanol systems may exhibit a different temperature response. It will also be noted that although the datasets include a significant amount of low acidity data, there is considerable scatter of the data in this region reducing confidence in model predictions in this region. The approach adopted was to exclude the highly scattered data at low acidity from the fitting process and confirm that the resultant model gives results within the range of the scatter at low acidity. Although relative errors in this region may be large, absolute errors will be small and for most practical applications of modelling flowsheets it will be absolute errors that are of concern.

When using the distribution algorithms described above, there is a requirement to bear in mind the limitations of the algorithms. These relate to the range of conditions covered by the data used in the fitting. The main limitations are summarised below:

\section{Extrapolation to very high acidity}

The organic phase speciation models underlying the distribution correlations described herein have been empirically derived such that the available data can be adequately explained. It is probable that the actual speciation of the organic phase is significantly more complex than that incorporated in the models. In particular it has been suggested that various organic phase aggregates may occur including tetramers and larger micelles. ${ }^{45} 46$ Although TODGA tetramers were considered in the fitting (as was the $\mathrm{HNO}_{3}$.4TODGA species), their addition to the model was not found to confer any benefit in the fitting of the available data. The use of an incomplete organic phase speciation model has the potential to curtail the reliability of the model beyond the range of the data used to derive it. Similarly, the aqueous phase activity effects are built into the empirical correlations and it cannot be assumed that these will extrapolate successfully. Such activity effects will become more important at higher acidity.

\section{Use with species other than nitric acid in the aqueous phase}

The derivation of the distribution correlations in this paper has employed mean stoichiometric activity coefficients. This approach is adequate provided that $\left[\mathrm{H}^{+}\right] \approx\left[\mathrm{NO}_{3}{ }^{-}\right]$. With appreciable quantities of e.g. metal nitrates in the aqueous phase this approximation will no longer be valid and it is likely that nitric acid distribution will vary from prediction, even if none of the additional aqueous phase species are extractable.

\section{Use with a metal loaded solvent phase}

When modelling solvent extraction systems it is normal to extend the continuity equation for the extractant to include terms for all organic phase species. In this way the effect of competition for the extractant from other species can be taken into account. In the case of TODGA based systems, the situation becomes more complicated as there is evidence that nitric acid co-extracts to a significant extent with actinide and lanthanide species. ${ }^{47}$ The nitric 
acid / metal cross complexes would need to be included in any model of nitric acid extraction in the presence of such metals if under-prediction of nitric acid extraction is to be avoided.

\section{Conclusions}

Sophisticated models for the extraction of nitric acid into octanol, TODGA, or TODGA + $5 \mathrm{v} / \mathrm{v} \%$ octanol were established, covering a range of nitric acid and TODGA concentrations and temperatures relevant to process modelling. While the octanol model is based on published experimental data, previously unavailable data on nitric acid extraction into TODGA and TODGA + (mostly) $5 \mathrm{v} / \mathrm{v} \%$ octanol were collected. An additive model for TODGA/octanol solvents, predicting nitric acid extraction into TODGA plus that resulting from nitric acid extraction into octanol, yields reasonable agreement with experimental data. However, nitric acid extraction is systematically under predicted for aqueous nitric acid concentrations above about $1.5 \mathrm{~mol} / \mathrm{L} \mathrm{HNO}_{3}$, while it is over predicted for lower nitric acid concentrations. Adding cross adducts, $i \mathrm{HNO}_{3} \cdot j \mathrm{TODGA} \cdot k \operatorname{Octanol}(i, j, k=(0,1,2),(1,1,1)$, $(2,1,3),(3,1,2)$, results in a significantly improved accuracy. Fitting of temperature series data $\left(10-50{ }^{\circ} \mathrm{C}\right)$ showed a temperature dependence dictated by the relationship

$$
H_{\text {orgT }}=2.58 \times 10^{-5} H_{\text {org } 293} e^{\frac{25700}{R T}}
$$

where $\mathrm{H}_{\text {orgT }}$ and $\mathrm{H}_{\text {org293 }}$ are the organic acid concentrations at temperature $\mathrm{T}$ and $293 \mathrm{~K}$ respectively. No diluent dependence was found for nitric acid extraction.

\section{Acknowledgements}

Financial support for this research was provided by the European Commission via the following projects: SACSESS - contract number FP7-Fission-2012-323-28 and GENIORS Horizon 2020 grant agreement № 755171 and NNL’s Advanced Recycling and Isotope Separation (ARIS) R\&D programme.

\section{References}

1. Dinh, B.; Moisy, P.; Baron, P.; Calor, J.-N.; Espinoux, D.; Lorrain, B.; Benchikouhne-Ranchoux, M., Modified PUREX first-cycle extraction for neptunium recovery. In Proc. Internat. Solvent Extr. Conf. (ISEC 2008), Moyer, B. A., Ed. Tucson, Arizona, USA, 15-19 September, 2008.

2. Taylor, R. J.; Gregson, C. R.; Carrott, M. J.; Mason, C.; Sarsfield, M. J., Progress towards the full recovery of neptunium in an advanced PUREX process. Solvent Extr. Ion Exch. 2013, 31 (4), 442-462.

3. Sasaki, Y.; Sugo, Y.; Suzuki, S.; Tachimori, S., The novel extractants, diglycolamides, for the extraction of lanthanides and actinides in HNO3/n-dodecane system. Solvent Extr. Ion Exch. 2001, 19 (1), 91103.

4. Ansari, S. A.; Pathak, P.; Mohapatra, P. K.; Manchanda, V. K., Chemistry of diglycolamides: promising extractants for actinide partitioning. Chem. Rev. 2012, 112 (3), 1751-1772.

5. Modolo, G.; Geist, A.; Miguirditchian, M., Minor actinide separations in the reprocessing of spent nuclear fuels: recent advances in Europe. In Reprocessing and Recycling of Spent Nuclear Fuel, Taylor, R., Ed. Woodhead Publishing: Cambridge, UK, 2015. 
6. Weaver, B.; Kappelmann, F. A. TALSPEAK: a new method of separating americium and curium from the lanthanides by extraction from an aqueous solution of an aminopolyacetic acid complex with a monoacidic organophosphate or phosphonate; USAEC report ORNL-3559, Oak Ridge National Laboratory, USA: 1964.

7. Nilsson, M.; Nash, K. L., Review article: a review of the development and operational characteristics of the TALSPEAK process. Solvent Extr. Ion Exch. 2007, 25 (6), 665-701.

8. Braley, J. C.; Grimes, T. S.; Nash, K. L., Alternatives to HDEHP and DTPA for simplified TALSPEAK separations. Ind. Eng. Chem. Res. 2012, 51 (2), 629-638.

9. Gelis, A. V.; Lumetta, G. J., Actinide lanthanide separation process-ALSEP. Ind. Eng. Chem. Res. 2014, 53 (4), 1624-1631.

10. Grimes, T. S.; Tillotson, R. D.; Martin, L. R., Trivalent Lanthanide/Actinide Separation Using Aqueous-Modified TALSPEAK Chemistry. Solvent Extr. Ion Exch. 2014, 32 (4), 378-390.

11. Lumetta, G. J.; Levitskaia, T. G.; Wilden, A.; Casella, A. J.; Hall, G. B.; Lin, L.; Sinkov, S. I.; Law, J. D.; Modolo, G., An Advanced TALSPEAK concept for separating minor actinides. Part 1. Process optimization and flowsheet development. Solvent Extr. Ion Exch. 2017, 35 (6), 377-395.

12. Wilden, A.; Lumetta, G. J.; Sadowski, F.; Schmidt, H.; Schneider, D.; Gerdes, M.; Law, J. D.; Geist, A.; Bosbach, D.; Modolo, G., An Advanced TALSPEAK concept for separating minor actinides. Part 2. Flowsheet test with actinide-spiked simulant. Solvent Extr. Ion Exch. 2017, 35 (6), 396-407.

13. Geist, A.; Müllich, U.; Magnusson, D.; Kaden, P.; Modolo, G.; Wilden, A.; Zevaco, T., Actinide(III)/lanthanide(III) separation via selective aqueous complexation of actinides(III) using a hydrophilic 2,6-bis(1,2,4-triazin-3-yl)-pyridine in nitric acid. Solvent Extr. Ion Exch. 2012, 30 (5), 433-444.

14. Wilden, A.; Modolo, G.; Kaufholz, P.; Sadowski, F.; Lange, S.; Sypula, M.; Magnusson, D.; Müllich, U.; Geist, A.; Bosbach, D., Laboratory-scale counter-current centrifugal contactor demonstration of an innovative-SANEX process using a water soluble BTP. Solvent Extr. Ion Exch. 2015, 33 (2), 91-108.

15. Ruff, C. M.; Müllich, U.; Geist, A.; Panak, P. J., Complexation of Cm(III) and Eu(III) with a hydrophilic 2,6-bis(1,2,4-triazin-3-yl)-pyridine studied by time-resolved laser fluorescence spectroscopy. Dalton Trans. 2012, 41, 14594-14602.

16. Macerata, E.; Mossini, E.; Scaravaggi, S.; Mariani, M.; Mele, A.; Panzeri, W.; Boubals, N.; Berthon, L.; Charbonnel, M.-C.; Sansone, F.; Arduini, A.; Casnati, A., Hydrophilic clicked 2,6-bis-triazolyl-pyridines endowed with high actinide selectivity and radiochemical stability: toward a closed nuclear fuel cycle. J. Amer. Chem. Soc. 2016, 138 (23), 7232-7235.

17. Wagner, C.; Mossini, E.; Macerata, E.; Mariani, M.; Arduini, A.; Casnati, A.; Geist, A.; Panak, P. J., Time-resolved laser fluorescence spectroscopy study of the coordination chemistry of a hydrophilic CHON [1,2,3-triazol-4-yl]pyridine ligand with Cm(III) and Eu(III). Inorg. Chem. 2017, 56 (4), 2135-2144.

18. Panak, P. J.; Geist, A., Complexation and extraction of trivalent actinides and lanthanides by triazinylpyridine N-donor ligands. Chem. Rev. 2013, 113 (2), 1199-1236.

19. Zhu, Y. J.; Chen, J.; Jiao, R. Z., Extraction of Am(III) and Eu(III) from nitrate solution with purified Cyanex 301. Solvent Extr. Ion Exch. 1996, 14 (1), 61-68.

20. Modolo, G.; Odoj, R., Synergistic selective extraction of actinides(III) over lanthanides from nitric acid using new aromatic diorganyldithiophosphinic acids and neutral organophosphorus compounds. Solvent Extr. Ion Exch. 1999, 17 (1), 33-53.

21. Alyapyshev, M.; Babain, V.; Tkachenko, L., Various flowsheets of actinides recovery with diamides of heterocyclic dicarboxylic acids. J. Radioanal. Nucl. Chem. 2017, 312 (1), 47-58. 
22. Whittaker, D.; Geist, A.; Modolo, G.; Taylor, R.; Sarsfield, M.; Wilden, A., Applications of diglycolamide based solvent extraction processes in spent nuclear fuel reprocessing, part 1: TODGA. Solvent Extr. Ion Exch. 2018, 36 (3), 223-256.

23. Modolo, G.; Asp, H.; Schreinemachers, C.; Vijgen, H., Development of a TODGA based process for partitioning of actinides from a PUREX raffinate part I: batch extraction optimization studies and stability tests. Solvent Extr. Ion Exch. 2007, 25 (6), 703-721.

24. McLachlan, F.; Greenough, K.; Geist, A.; McLuckie, B.; Modolo, G.; Wilden, A.; Taylor, R., Nitric acid extraction into the TODGA/TBP solvent. Solvent Extr. Ion Exch. 2016, 34 (4), 334-346.

25. Gujar, R. B.; Ansari, S. A.; Prabhu, D. R.; Pathak, P. N.; Sengupta, A.; Thulasidas, S. K.; Mohapatra, P. K.; Manchanda, V. K., Actinide Partitioning with a Modified TODGA Solvent: Counter-Current Extraction Studies with Simulated High Level Waste. Solvent Extr. Ion Exch. 2012, 30 (2), 156-170.

26. Gujar, R. B.; Dhekane, G. B.; Mohapatra, P. K., Liquid-liquid extraction of Np4+ and Pu4+ using several tetra-alkyl substituted diglycolamides. Radiochim. Acta 2013, 101 (11), 719-724.

27. Tachimori, S.; Sasaki, Y.; Suzuki, S.-I., Modification ofTODGA-n-dodecane solvent with a monoamide for high loading of lanthanides(III) and actinides(III). Solvent Extr. Ion Exch. 2002, 20 (6), 687699.

28. Ansari, S. A.; Pathak, P. N.; Manchanda, V. K.; Husain, M.; Prasad, A. K.; Parmar, V. S., N,N,N',N'tetraoctyl diglycolamide (TODGA): a promising extractant for actinide partitioning from high-level waste (HLW). Solvent Extr. Ion Exch. 2005, 23 (4), 463-479.

29. Sasaki, Y.; Zhu, Z.-X.; Sugo, Y.; Kimura, T., Extraction of various metal ions from nitric acid to ndodecanen by diglycolamide (DGA) compounds. J. Nucl. Sci. Technol. 2007, 44 (3), 405-409.

30. Brown, J.; McLachlan, F.; Sarsfield, M.; Taylor, R.; Modolo, G.; Wilden, A., Plutonium loading of prospective grouped actinide extraction (GANEX) solvent systems based on diglycolamide extractants. Solvent Extr. Ion Exch. 2012, 30 (2), 127-141.

31. Carrott, M.; Geist, A.; Hérès, X.; Lange, S.; Malmbeck, R.; Miguirditchian, M.; Modolo, G.; Wilden, A.; Taylor, R., Distribution of plutonium, americium and interfering fission products between nitric acid and a mixed organic phase of TODGA and DMDOHEMA in kerosene, and implications for the design of the "EUROGANEX" process. Hydrometallurgy 2015, 152, 139-148.

32. Geist, A.; Modolo, G., TODGA process development: an improved solvent formulation. In Proc. Internat. Conf. GLOBAL 2009 (The Nuclear Fuel Cycle: Sustainable Options \& Industrial Perspectives), Paris, 6-11 September, 2009; pp 1022-1026.

33. Xu, Y.; Gao, Y.; Zhou, Y.; Fan, C.; Hou, H.; Zhang, M., Extraction behavior of strontium from nitric acid medium with N,N'-dimethyl-N,N'-dioctyldiglcolamide. Solvent Extr. Ion Exch. 2017, 35 (7), 507-518.

34. Campbell, E. L.; Holfeltz, V. E.; Hall, G. B.; Nash, K. L.; Lumetta, G. J.; Levitskaia, T. G., Nitric acid and water extraction by T2EHDGA in n-dodecane. Solvent Extr. Ion Exch. 2017, 35 (7), 586-603.

35. Jensen, M. P.; Yaita, T.; Chiarizia, R., Reverse-micelle formation in the partitioning of trivalent felement cations by biphasic systems containing a tetraalkyldiglycolamide. Langmuir 2007, 23 (9), 4765-4774.

36. Pathak, P. N.; Ansari, S. A.; Kumar, S.; Tomar, B. S.; Manchanda, V. K., Dynamic light scattering study on the aggregation behaviour of $\mathrm{N}, \mathrm{N}, \mathrm{N}^{\prime}, \mathrm{N}^{\prime}$-tetraoctyl diglycolamide (TODGA) and its correlation with the extraction behaviour of metal ions. J. Colloid Interf. Sci. 2010, 342 (1), 114-118.

37. Geist, A., Extraction of nitric acid into alcohol:kerosene mixtures. Solvent Extr. Ion Exch. 2010, 28 (5), 596-607. 
38. Iqbal, M.; Huskens, J.; Verboom, W.; Sypula, M.; Modolo, G., Synthesis and Am/Eu extraction of novel TODGA derivatives. Supramolec. Chem. 2010, 22 (11/12), 827-837.

39. Ciavatta, L., The specific interaction theory in the evaluating ionic equilibria. Ann. Chim. (Rome) 1980, $70,551-562$.

40. Chaiko, D. J.; Vandegrift, G. F., A thermodynamic model of nitric acid extraction by tri-n-butyl phosphate. Nuclear Technology 1988, 82 (1), 52-59.

41. Pitzer, K. S., Thermodynamics of electrolytes. I. Theoretical basis and general equations. J. Phys. Chem. 1973, 77 (2), 268-277.

42. Gazith, M. Activity coefficients of various electrolytes - molal and molar concentrations; Israel Atomic Energy Commission, IA-1004: 1964.

43. Davis Jr, W.; De Bruin, H. J., New activity coefficients of 0-100 per cent aqueous nitric acid. J. Inorg. Nucl. Chem. 1964, 26 (6), 1069-1083.

44. Process Systems Enterprise, gPROMS, www.psenterprise.com/gproms, 1997-2018.

45. Yaita, T.; Herlinger, A. W.; Thiyagarajan, P.; Jensen, M. P., Influence of extractant aggregation on the extraction of trivalent f-element cations by a tetraalkyldiglycolamide. Solvent Extr. Ion Exch. 2004, 22 (4), 553571.

46. Nave, S.; Modolo, G.; Madic, C.; Testard, F., Aggregation properties of N,N,N',N'-tetraoctyl-3oxapentanediamide (TODGA) in n-dodecane. Solvent Extr. Ion Exch. 2004, 22 (4), 527-551.

47. Sasaki, Y.; Rapold, P.; Arisaka, M.; Hirata, M.; Kimura, T.; Hill, C.; Cote, G., An additional insight into the correlation between the distribution ratios and the aqueous acidity of the TODGA system. Solvent Extr. Ion Exch. 2007, 25 (2), 187-204. 


\section{Nitric Acid Extraction into a TODGA Solvent Modified with Octanol}

\section{- Supporting Information -}

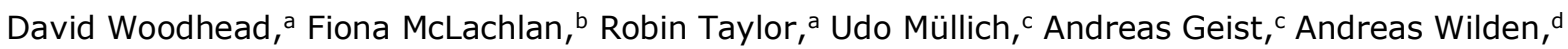
Giuseppe Modolod

a National Nuclear Laboratory, Central Laboratory, Sellafield, CA20 1PG, United Kingdom

b National Nuclear Laboratory, Building D5, Culham Science Centre, Abingdon, Oxfordshire, OX14 3DB, United Kingdom

c Karlsruhe Institute of Technology (KIT), Institute for Nuclear Waste Disposal (INE), Karlsruhe, Germany

d Forschungszentrum Jülich $\mathrm{GmbH}$, Institut für Energie- und Klimaforschung - Nukleare

Entsorgung und Reaktorsicherheit (IEK-6), Jülich, Germany

\section{Nitric Acid Extraction into Octanol / TPH Mixtures}

Extraction of $0.1-5.0 \mathrm{~mol} / \mathrm{L}$ nitric acid into $5-100 \mathrm{v} / \mathrm{v} \%$ octanol in TPH was measured at a temperature of $20 \pm 0.5^{\circ} \mathrm{C}$. Data as published in [Geist, A., Solvent Extr. Ion Exch. 2010, 28 (5), 596-607] are presented in Table SI 1 below.

Table SI 1: Extraction of Nitric Acid into Octanol / TPH

\begin{tabular}{|c|c|c|c|c|c|c|c|}
\hline $\begin{array}{c}{[\text { octanol }} \\
(\mathrm{v} / \mathrm{V} \%)\end{array}$ & $\begin{array}{c}{\left[\mathrm{HNO}_{3}\right]} \\
(\mathrm{aq}, \text { ini }) \\
(\mathrm{mol} / \mathrm{L})\end{array}$ & $\begin{array}{c}{\left[\mathrm{HNO}_{3}\right]} \\
(\mathrm{aq}, \text { eq }) \\
(\mathrm{mol} / \mathrm{L})\end{array}$ & $\begin{array}{c}{\left[\mathrm{HNO}_{3}\right]} \\
(\text { org, eq }) \\
(\mathrm{mol} / \mathrm{L})\end{array}$ & $\begin{array}{c}\text { Mass } \\
\text { Balance } \\
(\%)\end{array}$ & $\begin{array}{c}\mathrm{D} \\
\text { Fit? }\end{array}$ & $\begin{array}{c}\text { Estimated } \\
\text { Error }\end{array}$ \\
\hline 5 & 0.151 & 0.151 & 0.0000613 & 99.78 & 0.000407 & No $^{\text {a }}$ & \\
\hline 5 & 0.201 & 0.201 & 0.0000693 & 100.03 & 0.000345 & No $^{\text {a }}$ & \\
\hline 5 & 0.3 & 0.297 & 0.000112 & 98.84 & 0.000377 & Yes & $9.2 \%$ \\
\hline 5 & 0.498 & 0.498 & 0.0003 & 100.06 & 0.000602 & Yes & $7.0 \%$ \\
\hline 5 & 0.697 & 0.699 & 0.000504 & 100.36 & 0.000721 & Yes & $6.1 \%$ \\
\hline 5 & 0.998 & 0.998 & 0.00115 & 100.12 & 0.00115 & Yes & $4.8 \%$ \\
\hline 5 & 1.487 & 1.47 & 0.00264 & 99.04 & 0.0018 & Yes & $3.8 \%$ \\
\hline 5 & 1.991 & 1.966 & 0.00552 & 99.02 & 0.00281 & Yes & $3.1 \%$ \\
\hline 5 & 2.968 & 2.919 & 0.0146 & 98.83 & 0.00502 & Yes & $2.4 \%$ \\
\hline 5 & 3.964 & 3.88 & 0.0302 & 98.64 & 0.00779 & Yes & $2.0 \%$ \\
\hline 5 & 5 & 4.901 & 0.0499 & 99.03 & 0.0102 & Yes & $1.7 \%$ \\
\hline 10 & 0.151 & 0.152 & 0.000115 & 100.47 & 0.000758 & No & \\
\hline 10 & 0.201 & 0.201 & 0.000134 & 100.04 & 0.000666 & Yes & $8.8 \%$ \\
\hline 10 & 0.3 & 0.303 & 0.000235 & 100.88 & 0.000776 & Yes & $7.5 \%$ \\
\hline 10 & 0.495 & 0.508 & 0.00069 & 102.89 & 0.00136 & Yes & $5.6 \%$ \\
\hline 10 & 0.697 & 0.702 & 0.00126 & 100.9 & 0.00179 & Yes & $4.7 \%$ \\
\hline 10 & 0.998 & 0.994 & 0.00274 & 99.96 & 0.00276 & Yes & $3.8 \%$ \\
\hline 10 & 1.487 & 1.489 & 0.0064 & 100.6 & 0.0043 & Yes & $3.0 \%$ \\
\hline 10 & 1.991 & 2.005 & 0.0126 & 101.34 & 0.00627 & Yes & $2.5 \%$ \\
\hline 10 & 2.968 & 2.953 & 0.0325 & 100.59 & 0.011 & Yes & $1.9 \%$ \\
\hline
\end{tabular}




\begin{tabular}{|c|c|c|c|c|c|c|c|}
\hline $\begin{array}{c}\text { [octanol] } \\
(\mathrm{v} / \mathrm{v} \%)\end{array}$ & $\begin{array}{c}{\left[\mathrm{HNO}_{3}\right]} \\
(\mathrm{aq}, \mathrm{ini}) \\
(\mathrm{mol} / \mathrm{L})\end{array}$ & $\begin{array}{l}{\left[\mathrm{HNO}_{3}\right]} \\
(\mathrm{aq}, \mathrm{eq}) \\
(\mathrm{mol} / \mathrm{L})\end{array}$ & $\begin{array}{c}{\left[\mathrm{HNO}_{3}\right]} \\
(\mathrm{org}, \mathrm{eq}) \\
(\mathrm{mol} / \mathrm{L})\end{array}$ & $\begin{array}{c}\text { Mass } \\
\text { Balance } \\
(\%)\end{array}$ & D & $\begin{array}{l}\text { Used in } \\
\text { Fit? }\end{array}$ & $\begin{array}{c}\text { Estimated } \\
\text { Error }\end{array}$ \\
\hline 10 & 3.964 & 3.941 & 0.0636 & 101.02 & 0.0161 & Yes & $1.6 \%$ \\
\hline 10 & 5 & 4.947 & 0.106 & 101.05 & 0.0213 & Yes & $1.4 \%$ \\
\hline 30 & 0.101 & 0.099 & 0.00016 & 98.18 & 0.00162 & Yes & $8.3 \%$ \\
\hline 30 & 0.152 & 0.152 & 0.000311 & 100.2 & 0.00205 & Yes & $6.9 \%$ \\
\hline 30 & 0.201 & 0.202 & 0.000531 & 100.76 & 0.00263 & Yes & $6.0 \%$ \\
\hline 30 & 0.302 & 0.302 & 0.0011 & 100.36 & 0.00365 & Yes & $4.9 \%$ \\
\hline 30 & 0.498 & 0.498 & 0.00286 & 100.57 & 0.00574 & Yes & $3.8 \%$ \\
\hline 30 & 0.702 & 0.702 & 0.0056 & 100.87 & 0.00798 & Yes & $3.1 \%$ \\
\hline 30 & 1.01 & 0.985 & 0.0108 & 98.63 & 0.011 & Yes & $2.6 \%$ \\
\hline 30 & 1.5 & 1.497 & 0.0273 & 101.62 & 0.0182 & Yes & $2.0 \%$ \\
\hline 30 & 2.04 & 1.965 & 0.0478 & 98.67 & 0.0243 & Yes & $1.7 \%$ \\
\hline 30 & 3.06 & 2.908 & 0.122 & 99.01 & 0.0418 & Yes & $1.3 \%$ \\
\hline 30 & 3.964 & 3.769 & 0.211 & 100.4 & 0.0559 & Yes & $1.1 \%$ \\
\hline 30 & 5 & 4.77 & 0.339 & 102.17 & 0.071 & Yes & $1.0 \%$ \\
\hline 50 & 0.102 & 0.102 & 0.00032 & 99.92 & 0.00314 & Yes & $6.9 \%$ \\
\hline 50 & 0.152 & 0.153 & 0.00071 & 101.13 & 0.00464 & Yes & $5.5 \%$ \\
\hline 50 & 0.203 & 0.203 & 0.0012 & 100.39 & 0.00591 & Yes & $4.8 \%$ \\
\hline 50 & 0.299 & 0.303 & 0.00246 & 101.99 & 0.00813 & Yes & $3.9 \%$ \\
\hline 50 & 0.502 & 0.5 & 0.00625 & 100.91 & 0.0125 & Yes & $3.0 \%$ \\
\hline 50 & 0.702 & 0.701 & 0.012 & 101.64 & 0.0171 & Yes & $2.5 \%$ \\
\hline 50 & 1.004 & 0.98 & 0.0246 & 100.06 & 0.0251 & Yes & $2.1 \%$ \\
\hline 50 & 1.5 & 1.457 & 0.056 & 100.87 & 0.0384 & Yes & $1.7 \%$ \\
\hline 50 & 1.984 & 1.918 & 0.104 & 101.89 & 0.054 & Yes & $1.4 \%$ \\
\hline 50 & 2.977 & 2.789 & 0.233 & 101.49 & 0.0834 & Yes & $1.1 \%$ \\
\hline 50 & 3.98 & 3.661 & 0.394 & 101.88 & 0.108 & Yes & $0.96 \%$ \\
\hline 50 & 4.984 & 4.566 & 0.59 & 103.45 & 0.129 & Yes & $0.86 \%$ \\
\hline 100 & 0.1 & 0.103 & 0.00132 & 103.76 & 0.0128 & Yes & $4.7 \%$ \\
\hline 100 & 0.152 & 0.156 & 0.00295 & 104.6 & 0.0189 & $\mathrm{No}^{\mathrm{b}}$ & \\
\hline 100 & 0.201 & 0.202 & 0.00464 & 102.68 & 0.023 & Yes & $3.3 \%$ \\
\hline 100 & 0.304 & 0.301 & 0.00964 & 102.25 & 0.032 & Yes & $2.7 \%$ \\
\hline 100 & 0.508 & 0.499 & 0.0241 & 102.96 & 0.0483 & Yes & $2.1 \%$ \\
\hline 100 & 0.719 & 0.694 & 0.0464 & 102.97 & 0.0668 & Yes & $1.7 \%$ \\
\hline 100 & 1.016 & 0.946 & 0.0888 & 101.85 & 0.0938 & Yes & $1.5 \%$ \\
\hline 100 & 1.511 & 1.381 & 0.181 & 103.41 & 0.131 & Yes & $1.2 \%$ \\
\hline 100 & 2.017 & 1.785 & 0.3 & 103.35 & 0.168 & Yes & $1.0 \%$ \\
\hline 100 & 3.028 & 2.556 & 0.57 & 103.22 & 0.223 & Yes & $0.87 \%$ \\
\hline 100 & 4.045 & 3.334 & 0.871 & 103.95 & 0.261 & Yes & $0.77 \%$ \\
\hline 100 & 5 & 4.074 & 1.121 & 103.9 & 0.275 & $\mathrm{No}^{\mathrm{b}}$ & \\
\hline
\end{tabular}

a Outlier excluded from fitting

b Data received after fitting undertaken

Errors quoted are one standard deviation as reported by gPROMS. The absolute measurement errors are calculated by $\sigma=\omega|x|^{\gamma}$ where $\sigma$ is the standard deviation, $\omega$ and $\gamma$ are constants fitted in gPROMS (giving values 0.007437 and 0.7325 respectively) and $x$ is the measured value (in this 
case organic acidity). Errors at very low acidity, not included in the gPROMS fitting are likely to be larger than given by this formula.

\section{Nitric Acid Extraction into TODGA / Exxsol D80 Mixtures}

Extraction of $0.1-8.7 \mathrm{~mol} / \mathrm{L}$ nitric acid into $0.05-0.4 \mathrm{~mol} / \mathrm{L}$ TODGA in Exxsol D80 was measured with results as presented in Table SI 2 below.

Table SI 2: Extraction of Nitric Acid into TODGA / Exxsol D80

\begin{tabular}{|c|c|c|c|c|c|c|c|c|}
\hline Series & $\begin{array}{c}{[\text { TODGA }]} \\
(\mathrm{mol} / \mathrm{L})\end{array}$ & $\begin{array}{l}{\left[\mathrm{HNO}_{3}\right]} \\
(\mathrm{aq}, \mathrm{ini}) \\
(\mathrm{mol} / \mathrm{L})\end{array}$ & $\begin{array}{c}{\left[\mathrm{HNO}_{3}\right]} \\
(\mathrm{aq}, \mathrm{eq}) \\
(\mathrm{mol} / \mathrm{L})\end{array}$ & $\begin{array}{c}{\left[\mathrm{HNO}_{3}\right]} \\
\text { (org, eq) } \\
\text { (mol/L) }\end{array}$ & $\begin{array}{c}\text { Mass } \\
\text { Balance } \\
(\%)\end{array}$ & D & $\begin{array}{l}\text { Used in } \\
\text { Fitting? }\end{array}$ & $\begin{array}{c}\text { Estimated } \\
\text { Error }\end{array}$ \\
\hline 1 & 0.1 & 0.096 & 0.097 & 0.001 & 102.08 & 0.0103 & $\mathrm{No}^{\mathrm{a}}$ & \\
\hline 1 & 0.1 & 0.242 & 0.247 & 0.007 & 104.96 & 0.0283 & $\mathrm{No}^{\mathrm{a}}$ & \\
\hline 1 & 0.1 & 0.490 & 0.493 & 0.010 & 102.65 & 0.0203 & $\mathrm{No}^{\mathrm{a}}$ & \\
\hline 1 & 0.1 & 0.969 & 0.985 & 0.021 & 103.82 & 0.0213 & Yes & $27 \%$ \\
\hline 1 & 0.1 & 1.935 & 1.962 & 0.053 & 104.13 & 0.0270 & Yes & $14 \%$ \\
\hline 1 & 0.1 & 2.858 & 2.881 & 0.095 & 104.13 & 0.0330 & Yes & $9 \%$ \\
\hline 1 & 0.1 & 4.797 & 4.746 & 0.155 & 102.17 & 0.0327 & Yes & $6.3 \%$ \\
\hline 1 & 0.1 & 6.739 & 6.736 & 0.223 & 103.26 & 0.0331 & Yes & $4.8 \%$ \\
\hline 1 & 0.1 & 7.099 & 6.923 & 0.227 & 100.72 & 0.0328 & Yes & $4.7 \%$ \\
\hline 1 & 0.1 & 7.099 & 6.940 & 0.229 & 100.99 & 0.0330 & Yes & $4.7 \%$ \\
\hline 1 & 0.1 & 7.099 & 6.919 & 0.232 & 100.73 & 0.0335 & Yes & $4.7 \%$ \\
\hline 1 & 0.1 & 8.661 & 7.626 & 0.245 & 90.88 & 0.0321 & $\mathrm{No}^{\mathrm{b}}$ & \\
\hline 1 & 0.2 & 0.096 & 0.096 & 0.017 & 117.71 & 0.1771 & $\mathrm{No}^{\mathrm{ab}}$ & \\
\hline 1 & 0.2 & 0.242 & 0.244 & 0.024 & 110.74 & 0.0984 & $\mathrm{No}^{\mathrm{ab}}$ & \\
\hline 1 & 0.2 & 0.490 & 0.477 & 0.027 & 102.86 & 0.0566 & $\mathrm{No}^{\mathrm{a}}$ & \\
\hline 1 & 0.2 & 0.969 & 0.932 & 0.056 & 101.96 & 0.0601 & Yes & $13 \%$ \\
\hline 1 & 0.2 & 1.935 & 1.841 & 0.129 & 101.81 & 0.0701 & Yes & $7.2 \%$ \\
\hline 1 & 0.2 & 2.858 & 2.758 & 0.197 & 103.39 & 0.0714 & Yes & $5.3 \%$ \\
\hline 1 & 0.2 & 4.797 & 4.586 & 0.304 & 101.94 & 0.0663 & Yes & $3.8 \%$ \\
\hline 1 & 0.2 & 6.739 & 6.451 & 0.408 & 101.78 & 0.0632 & Yes & $3.1 \%$ \\
\hline 1 & 0.2 & 8.661 & 8.291 & 0.503 & 101.54 & 0.0607 & Yes & $2.7 \%$ \\
\hline 1 & 0.3 & 0.096 & 0.099 & 0.001 & 104.17 & 0.0101 & $\mathrm{No}^{\mathrm{a}}$ & \\
\hline 1 & 0.3 & 0.242 & 0.250 & 0.018 & 110.74 & 0.0720 & $\mathrm{No}^{\mathrm{ab}}$ & \\
\hline 1 & 0.3 & 0.490 & 0.493 & 0.021 & 104.90 & 0.0426 & $\mathrm{No}^{\mathrm{a}}$ & \\
\hline 1 & 0.3 & 1.020 & 0.962 & 0.104 & 104.51 & 0.1081 & Yes & $8.4 \%$ \\
\hline 1 & 0.3 & 2.056 & 1.878 & 0.222 & 102.14 & 0.1182 & Yes & $4.8 \%$ \\
\hline 1 & 0.3 & 3.025 & 2.750 & 0.320 & 101.49 & 0.1164 & Yes & $3.7 \%$ \\
\hline 1 & 0.3 & 4.797 & 4.523 & 0.458 & 103.84 & 0.1013 & Yes & $2.8 \%$ \\
\hline 1 & 0.3 & 7.099 & 6.632 & 0.663 & 102.76 & 0.1000 & Yes & $2.2 \%$ \\
\hline 1 & 0.3 & 8.661 & 7.373 & 0.702 & 93.23 & 0.0952 & $\mathrm{No}^{\mathrm{b}}$ & \\
\hline 4 & 0.05 & 0.969 & 0.994 & 0.010 & 103.61 & 0.0101 & Yes & $46 \%$ \\
\hline 4 & 0.075 & 0.969 & 0.986 & 0.016 & 103.41 & 0.0162 & Yes & $33 \%$ \\
\hline 4 & 0.1 & 0.969 & 0.979 & 0.019 & 102.99 & 0.0194 & Yes & $29 \%$ \\
\hline 4 & 0.15 & 0.969 & 0.972 & 0.024 & 102.79 & 0.0247 & Yes & $24 \%$ \\
\hline
\end{tabular}




\begin{tabular}{|c|c|c|c|c|c|c|c|c|}
\hline Series & $\begin{array}{c}{[\text { TODGA }]} \\
(\mathrm{mol} / \mathrm{L})\end{array}$ & $\begin{array}{l}{\left[\mathrm{HNO}_{3}\right]} \\
(\mathrm{aq}, \mathrm{ini}) \\
(\mathrm{mol} / \mathrm{L})\end{array}$ & $\begin{array}{c}{\left[\mathrm{HNO}_{3}\right]} \\
(\mathrm{aq}, \mathrm{eq}) \\
(\mathrm{mol} / \mathrm{L})\end{array}$ & $\begin{array}{c}{\left[\mathrm{HNO}_{3}\right]} \\
(\mathrm{org}, \mathrm{eq}) \\
(\mathrm{mol} / \mathrm{L})\end{array}$ & $\begin{array}{c}\text { Mass } \\
\text { Balance } \\
(\%)\end{array}$ & D & $\begin{array}{l}\text { Used in } \\
\text { Fitting? }\end{array}$ & $\begin{array}{c}\text { Estimated } \\
\text { Error }\end{array}$ \\
\hline 4 & 0.2 & 0.969 & 0.961 & 0.047 & 104.02 & 0.0489 & Yes & $15 \%$ \\
\hline 4 & 0.25 & 0.969 & 0.954 & 0.060 & 104.64 & 0.0629 & Yes & $13 \%$ \\
\hline 4 & 0.3 & 0.969 & 0.943 & 0.076 & 105.16 & 0.0806 & Yes & $11 \%$ \\
\hline 4 & 0.35 & 0.969 & 0.930 & 0.069 & 103.10 & 0.0742 & Yes & $11 \%$ \\
\hline 4 & 0.4 & 0.969 & 0.919 & 0.082 & 103.30 & 0.0892 & Yes & $10 \%$ \\
\hline 4 & 0.05 & 2.858 & 2.876 & 0.048 & 102.31 & 0.0167 & Yes & $15 \%$ \\
\hline 4 & 0.075 & 2.858 & 2.825 & 0.078 & 101.57 & 0.0276 & Yes & $10 \%$ \\
\hline 4 & 0.1 & 2.858 & 2.823 & 0.100 & 102.27 & 0.0354 & Yes & $8.6 \%$ \\
\hline 4 & 0.15 & 2.858 & 2.786 & 0.154 & 102.87 & 0.0553 & Yes & $6.3 \%$ \\
\hline 4 & 0.2 & 2.858 & 2.756 & 0.194 & 103.22 & 0.0704 & Yes & $5.3 \%$ \\
\hline 4 & 0.25 & 2.858 & 2.707 & 0.255 & 103.64 & 0.0942 & Yes & $4.4 \%$ \\
\hline 4 & 0.3 & 2.858 & 2.667 & 0.280 & 103.11 & 0.1050 & Yes & $4.1 \%$ \\
\hline 4 & 0.35 & 2.858 & 2.652 & 0.344 & 104.83 & 0.1297 & Yes & $3.5 \%$ \\
\hline 4 & 0.4 & 2.858 & 2.662 & 0.371 & 106.12 & 0.1394 & Yes & $3.3 \%$ \\
\hline 4 & 0.05 & 5.872 & 5.846 & 0.091 & 101.11 & 0.0156 & Yes & $9.3 \%$ \\
\hline 4 & 0.075 & 5.872 & 5.821 & 0.142 & 101.55 & 0.0244 & Yes & $6.7 \%$ \\
\hline 4 & 0.1 & 5.872 & 5.805 & 0.185 & 102.01 & 0.0319 & Yes & $5.5 \%$ \\
\hline 4 & 0.15 & 5.872 & 5.708 & 0.281 & 101.99 & 0.0492 & Yes & $4.1 \%$ \\
\hline 4 & 0.2 & 5.872 & 5.659 & 0.365 & 102.59 & 0.0645 & Yes & $3.4 \%$ \\
\hline 4 & 0.25 & 5.872 & 5.577 & 0.449 & 102.62 & 0.0805 & Yes & $2.9 \%$ \\
\hline 4 & 0.3 & 5.872 & 5.519 & 0.527 & 102.96 & 0.0955 & Yes & $2.6 \%$ \\
\hline 4 & 0.35 & 5.872 & 5.442 & 0.609 & 103.05 & 0.1119 & Yes & $2.3 \%$ \\
\hline 4 & 0.4 & 5.872 & 5.369 & 0.672 & 102.88 & 0.1252 & Yes & $2.2 \%$ \\
\hline 2 & 0.2 & 0.5 & 0.474 & 0.00886 & 96.47 & 0.0187 & $\mathrm{No}^{\mathrm{a}}$ & \\
\hline 2 & 0.2 & 0.7 & 0.677 & 0.022 & 99.86 & 0.0325 & Yes & $26 \%$ \\
\hline 2 & 0.2 & 1 & 0.951 & 0.0458 & 99.68 & 0.0482 & Yes & $15 \%$ \\
\hline 2 & 0.2 & 1.5 & 1.385 & 0.0885 & 98.23 & 0.0639 & Yes & $9.4 \%$ \\
\hline 2 & 0.2 & 2 & 1.875 & 0.128 & 100.15 & 0.0683 & Yes & $7.2 \%$ \\
\hline 2 & 0.2 & 3 & 2.763 & 0.191 & 98.47 & 0.0691 & Yes & $5.4 \%$ \\
\hline 2 & 0.2 & 5 & 4.765 & 0.304 & 101.38 & 0.0638 & Yes & $3.8 \%$ \\
\hline 2 & 0.1 & 8.568 & 8.41 & 0.282 & 101.45 & 0.0336 & Yes & $4.1 \%$ \\
\hline 2 & 0.1 & 8.568 & 8.402 & 0.281 & 101.34 & 0.0335 & Yes & $4.1 \%$ \\
\hline 2 & 0.2 & 8.568 & 8.202 & 0.540 & 102.02 & 0.0658 & Yes & $2.5 \%$ \\
\hline 2 & 0.2 & 8.568 & 8.225 & 0.542 & 102.32 & 0.0659 & Yes & $2.5 \%$ \\
\hline 2 & 0.3 & 8.568 & 8.027 & 0.796 & 102.96 & 0.0991 & Yes & $1.9 \%$ \\
\hline 2 & 0.3 & 8.568 & 8.06 & 0.799 & 103.39 & 0.0991 & Yes & $1.9 \%$ \\
\hline 3 & 0.2 & 1.031 & 1.015 & 0.091 & 107.26 & 0.0893 & $\mathrm{No}^{\mathrm{C}}$ & \\
\hline 3 & 0.2 & 2.033 & 1.922 & 0.177 & 103.23 & 0.0922 & $\mathrm{No}^{\mathrm{C}}$ & \\
\hline 3 & 0.2 & 2.954 & 2.741 & 0.237 & 100.84 & 0.0865 & $\mathrm{No}^{\mathrm{c}}$ & \\
\hline 3 & 0.2 & 5.265 & 5.008 & 0.373 & 102.21 & 0.0745 & $\mathrm{No}^{\mathrm{C}}$ & \\
\hline
\end{tabular}

a Data at below $0.6 \mathrm{M}$ aq acidity excluded from fitting.

b Data excluded from fitting due to poor mass balance.

c Series 3 data not used in fitting due to systematic offset from remainder of data 
Errors quoted are one standard deviation as reported by gPROMS. The absolute measurement errors are calculated by $\sigma=\omega|x|^{\vee}$ where $\sigma$ is the standard deviation, $\omega$ and $\gamma$ are constants fitted in gPROMS (giving values 0.01609 and 0.2701 respectively) and $x$ is the measured value (in this case organic acidity). Errors at very low acidity, not included in the gPROMS fitting are likely to be larger than given by this formula.

Series 1 and 4, Exxsol D80 diluent, ambient temperature $\left(\approx 20-25^{\circ} \mathrm{C}\right), A / O=1$. Series 2 , Exxsol D80 diluent, $20 \pm 0.5^{\circ} \mathrm{C}, A / O=1$. Series 3, Exxsol D80 diluent $22 \pm 1{ }^{\circ} \mathrm{C}, A / O=1$.

\section{Diluent Effect on Nitric Acid Extraction}

The extraction of $3 \mathrm{~mol} / \mathrm{L}$ nitric acid into $0.1 \mathrm{~mol} / \mathrm{L}$ TODGA $+5 \mathrm{v} / \mathrm{v} \%$ octanol in TPH, Exxsol D80, Fluka kerosene or $n$-dodecane was measured. Duplicate experiments with duplicate titrations each were performed at a temperature of $20^{\circ} \mathrm{C}$ and an $A / O$ phase ratio of 1 . The equilibrium nitric acid concentrations as determined by potentiometric titration after stripping into water $(A / O=2)$ in the organic phases are as follows:

$$
\begin{array}{ll}
\mathrm{TPH}, & (132 \pm 1) \mathrm{mmol} / \mathrm{L} \\
\text { Exxsol D80, } & (127 \pm 8) \mathrm{mmol} / \mathrm{L} \\
\text { Fluka kerosene, } & (128 \pm 3) \mathrm{mmol} / \mathrm{L} \\
\text { n-dodecane, } & (131 \pm 3) \mathrm{mmol} / \mathrm{L}
\end{array}
$$

The results imply that the kind of "kerosene" used does not have a significant effect on $\mathrm{HNO}_{3}$ extraction.

\section{Nitric Acid Extraction into TODGA / Octanol / Diluent Mixtures at $20-25^{\circ} \mathrm{C}$}

Extraction of $0.1-5.4 \mathrm{~mol} / \mathrm{L}$ nitric acid into $0.05-0.4 \mathrm{~mol} / \mathrm{L}$ TODGA, $5-50 \mathrm{v} / \mathrm{v} \%$ octanol in Exxsol D80 or TPH diluent was measured with results as presented in Table SI 3 below.

Table SI 3: Ambient Temperature Data for Nitric Acid Extraction into TODGA/Octanol/Diluent Mixtures

\begin{tabular}{|c|c|c|c|c|c|c|c|c|c|}
\hline Series & $\begin{array}{c}{[\text { Octanol }} \\
(\mathrm{mol} / \mathrm{L})\end{array}$ & $\begin{array}{c}{\left[\mathrm{TODGA}^{2}\right]} \\
(\mathrm{mol} / \mathrm{L})\end{array}$ & $\begin{array}{c}{\left[\mathrm{HNO}_{3}\right]} \\
(\mathrm{aq}, \mathrm{ini}) \\
(\mathrm{mol} / \mathrm{L})\end{array}$ & $\begin{array}{c}{\left[\mathrm{HNO}_{3}\right]} \\
(\mathrm{aq}, \mathrm{eq}) \\
(\mathrm{mol} / \mathrm{L})\end{array}$ & $\begin{array}{c}{\left[\mathrm{HNO}_{3}\right]} \\
(\mathrm{org}, \\
\text { eq }) \\
(\mathrm{mol} / \mathrm{L})\end{array}$ & $\begin{array}{c}\text { Mass } \\
\text { Balance } \\
(\%)\end{array}$ & $\mathrm{D}$ & $\begin{array}{c}\text { Used } \\
\text { in } \\
\text { Fitting }\end{array}$ & $\begin{array}{c}\text { Estimated } \\
\text { Error }\end{array}$ \\
\hline 1 & 0.316 & 0.2 & 0.096 & 0.096 & $1 \mathrm{E}-6$ & 100.00 & $1 \mathrm{E}-05$ & $\mathrm{No}^{\mathrm{a}}$ & \\
\hline 1 & 0.316 & 0.2 & 0.242 & 0.24 & 0.014 & 104.96 & 0.0583 & $\mathrm{No}^{\mathrm{a}}$ & \\
\hline 1 & 0.316 & 0.2 & 0.490 & 0.475 & 0.022 & 101.43 & 0.0463 & $\mathrm{No}^{\mathrm{a}}$ & \\
\hline 1 & 0.316 & 0.2 & 0.969 & 0.935 & 0.043 & 100.93 & 0.0460 & Yes & $6.3 \%$ \\
\hline 1 & 0.316 & 0.2 & 1.935 & 1.832 & 0.121 & 100.93 & 0.0660 & Yes & $6.1 \%$ \\
\hline 1 & 0.316 & 0.2 & 2.858 & 2.743 & 0.208 & 103.25 & 0.0758 & Yes & $5.9 \%$ \\
\hline 1 & 0.316 & 0.2 & 3.887 & 3.667 & 0.281 & 101.57 & 0.0766 & Yes & $5.9 \%$ \\
\hline 1 & 0.316 & 0.2 & 4.797 & 4.55 & 0.351 & 102.17 & 0.0771 & Yes & $5.8 \%$ \\
\hline 1 & 0.316 & 0.2 & 2.794 & 2.564 & 0.184 & 98.35 & 0.0718 & Yes & $6 \%$ \\
\hline 1 & 0.631 & 0.2 & 2.794 & 2.586 & 0.203 & 99.82 & 0.0785 & Yes & $5.9 \%$ \\
\hline 1 & 1.251 & 0.2 & 2.794 & 2.510 & 0.245 & 98.60 & 0.0976 & Yes & $5.9 \%$ \\
\hline
\end{tabular}




\begin{tabular}{|c|c|c|c|c|c|c|c|c|c|}
\hline Series & $\begin{array}{c}\text { [Octanol] } \\
(\mathrm{mol} / \mathrm{L})\end{array}$ & $\begin{array}{c}{[\text { TODGA] }} \\
(\mathrm{mol} / \mathrm{L})\end{array}$ & $\begin{array}{l}{\left[\mathrm{HNO}_{3}\right]} \\
(\mathrm{aq}, \mathrm{ini}) \\
(\mathrm{mol} / \mathrm{L})\end{array}$ & $\begin{array}{c}{\left[\mathrm{HNO}_{3}\right]} \\
(\mathrm{aq}, \mathrm{eq}) \\
(\mathrm{mol} / \mathrm{L})\end{array}$ & $\begin{array}{c}{\left[\mathrm{HNO}_{3}\right]} \\
\text { (org, } \\
\text { eq) } \\
(\mathrm{mol} / \mathrm{L} \text { ) }\end{array}$ & $\begin{array}{c}\text { Mass } \\
\text { Balance } \\
(\%)\end{array}$ & $D$ & $\begin{array}{l}\text { Used } \\
\text { in } \\
\text { Fitting }\end{array}$ & $\begin{array}{c}\text { Estimated } \\
\text { Error }\end{array}$ \\
\hline 1 & 1.880 & 0.2 & 2.794 & 2.452 & 0.292 & 98.21 & 0.1191 & Yes & $5.8 \%$ \\
\hline 1 & 2.493 & 0.2 & 2.794 & 2.510 & 0.325 & 101.47 & 0.1295 & Yes & $5.8 \%$ \\
\hline 1 & 3.110 & 0.2 & 2.794 & 2.428 & 0.337 & 98.96 & 0.1388 & Yes & $5.8 \%$ \\
\hline 1 & 0.316 & 0.3 & 2.858 & 2.655 & 0.299 & 103.36 & 0.1126 & Yes & $5.8 \%$ \\
\hline 1 & 0.631 & 0.3 & 2.858 & 2.638 & 0.317 & 103.39 & 0.1202 & Yes & $5.8 \%$ \\
\hline 1 & 0.941 & 0.3 & 2.858 & 2.628 & 0.331 & 103.53 & 0.1260 & Yes & $5.8 \%$ \\
\hline 1 & 1.251 & 0.3 & 2.858 & 2.608 & 0.355 & 103.67 & 0.1361 & Yes & $5.8 \%$ \\
\hline 1 & 1.562 & 0.3 & 2.858 & 2.527 & 0.377 & 101.61 & 0.1492 & Yes & $5.8 \%$ \\
\hline 1 & 1.880 & 0.3 & 2.858 & 2.507 & 0.396 & 101.57 & 0.1580 & Yes & $5.8 \%$ \\
\hline 1 & 2.493 & 0.3 & 2.858 & 2.424 & 0.440 & 100.21 & 0.1815 & Yes & $5.8 \%$ \\
\hline 1 & 2.804 & 0.3 & 2.858 & 2.38 & 0.465 & 99.55 & 0.1954 & Yes & $5.7 \%$ \\
\hline 1 & 3.110 & 0.3 & 2.858 & 2.417 & 0.470 & 101.01 & 0.1945 & Yes & $5.7 \%$ \\
\hline 1 & 0.316 & 0.1 & 2.858 & 2.821 & 0.121 & 102.94 & 0.0429 & Yes & $6.1 \%$ \\
\hline 1 & 0.631 & 0.1 & 2.858 & 2.782 & 0.144 & 102.38 & 0.0518 & Yes & $6 \%$ \\
\hline 1 & 0.941 & 0.1 & 2.858 & 2.711 & 0.162 & 100.52 & 0.0598 & Yes & $6 \%$ \\
\hline 1 & 1.251 & 0.1 & 2.858 & 2.695 & 0.180 & 100.59 & 0.0668 & Yes & $6 \%$ \\
\hline 1 & 1.562 & 0.1 & 2.858 & 2.655 & 0.200 & 99.90 & 0.0753 & Yes & $5.9 \%$ \\
\hline 1 & 1.880 & 0.1 & 2.858 & 2.639 & 0.221 & 100.07 & 0.0837 & Yes & $5.9 \%$ \\
\hline 1 & 2.493 & 0.1 & 2.858 & 2.601 & 0.264 & 100.24 & 0.1015 & Yes & $5.9 \%$ \\
\hline 1 & 2.804 & 0.1 & 2.858 & 2.561 & 0.291 & 99.79 & 0.1136 & Yes & $5.9 \%$ \\
\hline 1 & 0.316 & 0.05 & 2.858 & 2.845 & 0.064 & 101.78 & 0.0225 & Yes & $6.2 \%$ \\
\hline 1 & 0.316 & 0.075 & 2.858 & 2.814 & 0.088 & 101.54 & 0.0313 & Yes & $6.1 \%$ \\
\hline 1 & 0.316 & 0.1 & 2.858 & 2.815 & 0.110 & 102.34 & 0.0391 & Yes & $6.1 \%$ \\
\hline 1 & 0.316 & 0.15 & 2.858 & 2.755 & 0.155 & 101.82 & 0.0563 & Yes & $6 \%$ \\
\hline 1 & 0.316 & 0.2 & 2.858 & 2.732 & 0.190 & 102.24 & 0.0695 & Yes & $6 \%$ \\
\hline 1 & 0.316 & 0.25 & 2.858 & 2.652 & 0.250 & 101.54 & 0.0943 & Yes & $5.9 \%$ \\
\hline 1 & 0.316 & 0.3 & 2.858 & 2.645 & 0.286 & 102.55 & 0.1081 & Yes & $5.9 \%$ \\
\hline 1 & 0.316 & 0.35 & 2.858 & 2.615 & 0.336 & 103.25 & 0.1285 & Yes & $5.8 \%$ \\
\hline 1 & 0.316 & 0.4 & 2.858 & 2.581 & 0.356 & 102.76 & 0.1379 & Yes & $5.8 \%$ \\
\hline 2 & 0.316 & 0.05 & 0.5 & 0.498 & $2.28 \mathrm{E}-3$ & & $0.0046^{c}$ & $\mathrm{No}^{\mathrm{a}}$ & \\
\hline 2 & 0.316 & 0.05 & 0.7 & 0.695 & $4.75 \mathrm{E}-3$ & & $0.0068^{c}$ & Yes & $6.9 \%$ \\
\hline 2 & 0.316 & 0.05 & 1 & 0.990 & 0.0103 & & $0.0104^{c}$ & Yes & $6.7 \%$ \\
\hline 2 & 0.316 & 0.05 & 1.5 & 1.478 & 0.0222 & & $0.0150^{\mathrm{c}}$ & Yes & $6.5 \%$ \\
\hline 2 & 0.316 & 0.05 & 2 & 1.962 & 0.0382 & & $0.0195^{c}$ & Yes & $6.4 \%$ \\
\hline 2 & 0.316 & 0.05 & 3 & 2.924 & 0.0758 & & $0.0259^{c}$ & Yes & $6.2 \%$ \\
\hline 2 & 0.316 & 0.05 & 4 & 3.887 & 0.113 & & $0.0291^{\mathrm{c}}$ & Yes & $6.1 \%$ \\
\hline 2 & 0.316 & 0.05 & 5 & 4.849 & 0.1511 & & $0.0312^{c}$ & Yes & $6 \%$ \\
\hline 2 & 0.316 & 0.1 & 0.296 & 0.293 & 0.003 & & 0.0119 & $\mathrm{No}^{\mathrm{a}}$ & \\
\hline 2 & 0.316 & 0.1 & 0.487 & 0.481 & 0.006 & & 0.0127 & $\mathrm{No}^{\mathrm{a}}$ & \\
\hline 2 & 0.316 & 0.1 & 0.980 & 0.961 & 0.019 & & 0.0195 & Yes & $6.5 \%$ \\
\hline 2 & 0.316 & 0.1 & 1.460 & 1.422 & 0.039 & & 0.0271 & Yes & $6.4 \%$ \\
\hline 2 & 0.316 & 0.1 & 1.950 & 1.884 & 0.066 & & 0.0349 & Yes & $6.2 \%$ \\
\hline 2 & 0.316 & 0.1 & 2.910 & 2.795 & 0.115 & & 0.0411 & Yes & $6.1 \%$ \\
\hline 2 & 0.316 & 0.1 & 3.890 & 3.720 & 0.170 & & 0.0458 & Yes & $6 \%$ \\
\hline
\end{tabular}




\begin{tabular}{|c|c|c|c|c|c|c|c|c|c|}
\hline Series & $\begin{array}{c}\text { [Octanol] } \\
(\mathrm{mol} / \mathrm{L})\end{array}$ & $\begin{array}{c}{[\text { TODGA }]} \\
(\mathrm{mol} / \mathrm{L})\end{array}$ & $\begin{array}{c}{\left[\mathrm{HNO}_{3}\right]} \\
(\mathrm{aq}, \mathrm{ini}) \\
(\mathrm{mol} / \mathrm{L})\end{array}$ & $\begin{array}{c}{\left[\mathrm{HNO}_{3}\right]} \\
(\mathrm{aq}, \mathrm{eq}) \\
(\mathrm{mol} / \mathrm{L})\end{array}$ & $\begin{array}{c}{\left[\mathrm{HNO}_{3}\right]} \\
\text { (org, } \\
\text { eq) } \\
(\mathrm{mol} / \mathrm{L})\end{array}$ & $\begin{array}{c}\text { Mass } \\
\text { Balance } \\
(\%)\end{array}$ & D & $\begin{array}{c}\text { Used } \\
\text { in } \\
\text { Fitting }\end{array}$ & $\begin{array}{c}\text { Estimated } \\
\text { Error }\end{array}$ \\
\hline 2 & 0.316 & 0.1 & 4.900 & 4.681 & 0.219 & & 0.0468 & Yes & $5.9 \%$ \\
\hline 2 & 0.316 & 0.2 & 0.100 & 0.096 & 0.004 & & 0.0412 & $\mathrm{No}^{\mathrm{a}}$ & \\
\hline 2 & 0.316 & 0.2 & 0.199 & 0.194 & 0.005 & & 0.0253 & $\mathrm{No}^{\mathrm{a}}$ & \\
\hline 2 & 0.316 & 0.2 & 0.296 & 0.290 & 0.006 & & 0.0209 & $\mathrm{No}^{\mathrm{a}}$ & \\
\hline 2 & 0.316 & 0.2 & 0.487 & 0.474 & 0.013 & & 0.0277 & $\mathrm{No}^{\mathrm{a}}$ & \\
\hline 2 & 0.316 & 0.2 & 0.685 & 0.663 & 0.022 & & 0.0332 & Yes & $6.5 \%$ \\
\hline 2 & 0.316 & 0.2 & 0.980 & 0.937 & 0.043 & & 0.0457 & Yes & $6.3 \%$ \\
\hline 2 & 0.316 & 0.2 & 1.459 & 1.377 & 0.081 & & 0.0591 & Yes & $6.2 \%$ \\
\hline 2 & 0.316 & 0.2 & 1.953 & 1.823 & 0.130 & & 0.0716 & Yes & $6 \%$ \\
\hline 2 & 0.316 & 0.2 & 2.911 & 2.699 & 0.212 & & 0.0786 & Yes & $5.9 \%$ \\
\hline 2 & 0.316 & 0.2 & 3.887 & 3.581 & 0.306 & & 0.0855 & Yes & $5.8 \%$ \\
\hline 2 & 0.316 & 0.2 & 4.902 & 4.521 & 0.381 & & 0.0843 & Yes & $5.8 \%$ \\
\hline 2 & 0.316 & 0.3 & 0.296 & 0.286 & 0.010 & & 0.0335 & $\mathrm{No}^{\mathrm{a}}$ & \\
\hline 2 & 0.316 & 0.3 & 0.487 & 0.466 & 0.021 & & 0.0451 & $\mathrm{No}^{\mathrm{a}}$ & \\
\hline 2 & 0.316 & 0.3 & 0.685 & 0.649 & 0.036 & & 0.0556 & Yes & $6.4 \%$ \\
\hline 2 & 0.316 & 0.3 & 0.980 & 0.911 & 0.069 & & 0.0761 & Yes & $6.2 \%$ \\
\hline 2 & 0.316 & 0.3 & 1.460 & 1.336 & 0.124 & & 0.0928 & Yes & $6.1 \%$ \\
\hline 2 & 0.316 & 0.3 & 1.950 & 1.751 & 0.199 & & 0.1136 & Yes & $5.9 \%$ \\
\hline 2 & 0.316 & 0.3 & 2.910 & 2.607 & 0.303 & & 0.1162 & Yes & $5.8 \%$ \\
\hline 2 & 0.316 & 0.3 & 3.890 & 3.465 & 0.425 & & 0.1227 & Yes & $5.8 \%$ \\
\hline 2 & 0.316 & 0.3 & 4.900 & 4.381 & 0.519 & & 0.1185 & Yes & $5.7 \%$ \\
\hline 3 & 0.316 & 0.2 & 0.519 & 0.508 & 0.020 & 101.64 & 0.0394 & $\mathrm{No}^{\mathrm{a}}$ & \\
\hline 3 & 0.316 & 0.2 & 1.020 & 0.982 & 0.050 & 101.18 & 0.0509 & Yes & $6.3 \%$ \\
\hline 3 & 0.316 & 0.2 & 2.017 & 1.882 & 0.150 & 100.74 & 0.0797 & Yes & $6 \%$ \\
\hline 3 & 0.316 & 0.2 & 4.025 & 3.690 & 0.340 & 100.11 & 0.0922 & Yes & $5.8 \%$ \\
\hline 3 & 0.316 & 0.2 & 4.989 & 4.609 & 0.460 & 101.60 & 0.0998 & Yes & $5.7 \%$ \\
\hline 3 & 0.316 & 0.2 & 5.354 & 4.894 & 0.440 & 99.62 & 0.0899 & Yes & $5.8 \%$ \\
\hline 3 & 0.316 & 0.1 & 0.519 & 0.517 & 0.010 & 101.58 & 0.0201 & $\mathrm{No}^{\mathrm{a}}$ & \\
\hline 3 & 0.316 & 0.1 & 1.020 & 0.995 & 0.023 & 99.84 & 0.0232 & Yes & $6.5 \%$ \\
\hline 3 & 0.316 & 0.1 & 2.017 & 1.947 & 0.079 & 100.41 & 0.0405 & Yes & $6.2 \%$ \\
\hline 3 & 0.316 & 0.1 & 4.025 & 3.845 & 0.202 & 100.55 & 0.0526 & Yes & $5.9 \%$ \\
\hline 3 & 0.316 & 0.1 & 4.989 & 4.740 & 0.270 & 100.42 & 0.0571 & Yes & $5.9 \%$ \\
\hline 3 & 0.316 & 0.1 & 5.354 & 5.062 & 0.271 & 99.61 & 0.0535 & Yes & $5.9 \%$ \\
\hline 3 & 0.316 & 0.3 & 0.519 & 0.500 & 0.028 & 101.77 & 0.0560 & $\mathrm{No}^{\mathrm{a}}$ & \\
\hline 3 & 0.316 & 0.3 & 1.020 & 0.968 & 0.075 & 102.25 & 0.0775 & Yes & $6.2 \%$ \\
\hline 3 & 0.316 & 0.3 & 2.017 & 1.848 & 0.214 & 102.21 & 0.1158 & Yes & $5.9 \%$ \\
\hline 3 & 0.316 & 0.3 & 4.025 & 3.634 & 0.445 & 101.33 & 0.1225 & Yes & $5.7 \%$ \\
\hline 3 & 0.316 & 0.3 & 4.989 & 4.526 & 0.565 & 102.04 & 0.1248 & Yes & $5.7 \%$ \\
\hline 3 & 0.316 & 0.3 & 5.354 & 4.809 & 0.573 & 100.51 & 0.1192 & Yes & $5.7 \%$ \\
\hline
\end{tabular}

a Points at less than $0.6 \mathrm{M} \mathrm{HNO}_{3}(\mathrm{aq})(\mathrm{eq})$ excluded from fitting

Errors quoted are one standard deviation as reported by gPROMS. The absolute measurement errors are calculated by $\sigma=\omega|x|^{\vee}$ where $\sigma$ is the standard deviation, $\omega$ and $\gamma$ are constants fitted in 
gPROMS (giving values 0.05561 and 0.9590 respectively) and $x$ is the measured value (in this case organic acidity). Errors at very low acidity, not included in the gPROMS fitting are likely to be larger than given by this formula.

Four points from Table SI 4 (at $20^{\circ} \mathrm{C}$ ) were also used in fitting of TODGA / octanol cross complexes.

$0.316 \mathrm{~mol} / \mathrm{L}$ octanol equivalent to $5 \mathrm{v} / \mathrm{v} \%$ octanol.

Series 1 experiments used ambient temperature $\left(\approx 20-25^{\circ} \mathrm{C}\right)$ and Exxsol D80 diluent, $A / O=1$. Series 2 experiments undertaken at $20 \pm 0.5^{\circ} \mathrm{C}$ with TPH diluent, $A / O=1$. Equilibrium aqueous acidity was not measured in series 2 experiments and values in table above are from mass balance. Series 3 experiments undertaken at $22 \pm 1{ }^{\circ} \mathrm{C}$ with TPH diluent, $A / O=1$.

\section{Temperature Effect on Nitric Acid Extraction}

The extraction of nitric acid into 0.1 and $0.2 \mathrm{~mol} / \mathrm{L}$ TODGA in diluent with $5 \%$ octanol was measured. Results are reported in Table SI 4 below. Series 1 experiments used Exxsol D80 as a diluent whilst series 2 experiments used a TPH diluent. Equilibrium aqueous acidity calculated by mass balance, $A / O=1$ in all experiments.

Table SI 4: Experimental Data for Extraction of Nitric acid into TODGA /5\% Octanol/Diluent: Effect of Temperature

\begin{tabular}{|c|c|c|c|c|c|c|c|c|}
\hline Series & $\mathrm{T}\left({ }^{\circ} \mathrm{C}\right)$ & $\begin{array}{c}{[\mathrm{TODGA}]} \\
(\mathrm{mol} / \mathrm{L})\end{array}$ & $\begin{array}{c}{\left[\mathrm{HNO}_{3}\right]} \\
(\mathrm{aq}, \mathrm{ini}) \\
(\mathrm{mol} / \mathrm{L})\end{array}$ & $\begin{array}{c}{\left[\mathrm{HNO}_{3}\right]} \\
(\mathrm{aq}, \mathrm{eq}) \\
(\mathrm{mol} / \mathrm{L})\end{array}$ & $\begin{array}{c}{\left[\mathrm{HNO}_{3}\right]} \\
(\mathrm{org}, \text { eq }) \\
(\mathrm{Mol} / \mathrm{L})\end{array}$ & $\mathrm{D}$ & $\begin{array}{c}\text { Used in } \\
\text { Fitting? }\end{array}$ & $\begin{array}{c}\text { Estimated } \\
\text { error }\end{array}$ \\
\hline 1 & 22 & 0.2 & 1.021 & 0.977 & 0.0440 & 0.0450 & Yes & $4.8 \%$ \\
\hline 1 & 29.6 & 0.2 & 1.028 & 0.990 & 0.0380 & 0.0384 & Yes & $4.9 \%$ \\
\hline 1 & 38.9 & 0.2 & 1.057 & 1.020 & 0.0370 & 0.0363 & Yes & $4.9 \%$ \\
\hline 1 & 49.9 & 0.2 & 1.061 & 1.030 & 0.0310 & 0.0301 & Yes & $5 \%$ \\
\hline 2 & 10 & 0.1 & 0.306 & 0.303 & 0.0024 & 0.0099 & $\mathrm{No}^{\mathrm{a}}$ & \\
\hline 2 & 20 & 0.1 & 0.306 & 0.304 & 0.0020 & 0.0066 & $\mathrm{No}^{\mathrm{a}}$ & \\
\hline 2 & 30 & 0.1 & 0.306 & 0.304 & 0.0020 & 0.0079 & $\mathrm{No}^{\mathrm{a}}$ & \\
\hline 2 & 40 & 0.1 & 0.306 & 0.304 & 0.0017 & 0.0066 & $\mathrm{No}^{\mathrm{a}}$ & \\
\hline 2 & 50 & 0.1 & 0.306 & 0.304 & 0.0016 & 0.0053 & $\mathrm{No}^{\mathrm{a}}$ & \\
\hline 2 & 10 & 0.1 & 1.020 & 0.995 & 0.0252 & 0.0253 & Yes & $5.2 \%$ \\
\hline 2 & 20 & 0.1 & 1.020 & 1.000 & 0.0200 & 0.0200 & Yes & $5.4 \%{ }^{\mathrm{b}}$ \\
\hline 2 & 30 & 0.1 & 1.020 & 1.002 & 0.0176 & 0.0176 & Yes & $5.5 \%$ \\
\hline 2 & 40 & 0.1 & 1.020 & 1.005 & 0.0152 & 0.0151 & Yes & $5.6 \%$ \\
\hline 2 & 50 & 0.1 & 1.020 & 1.006 & 0.0144 & 0.0143 & Yes & $5.7 \%$ \\
\hline 2 & 10 & 0.1 & 3.050 & 2.918 & 0.1320 & 0.0452 & Yes & $4 \%$ \\
\hline 2 & 20 & 0.1 & 3.050 & 2.927 & 0.1230 & 0.0420 & Yes & $4.1 \%{ }^{\mathrm{c}}$ \\
\hline 2 & 30 & 0.1 & 3.050 & 2.936 & 0.1140 & 0.0388 & Yes & $4.1 \%$ \\
\hline 2 & 40 & 0.1 & 3.050 & 2.941 & 0.1090 & 0.0371 & Yes & $4.1 \%$ \\
\hline 2 & 50 & 0.1 & 3.050 & 2.945 & 0.1050 & 0.0357 & Yes & $4.2 \%$ \\
\hline 2 & 10 & 0.2 & 0.306 & 0.299 & 0.0072 & 0.0241 & $\mathrm{No}^{\mathrm{a}}$ & \\
\hline 2 & 20 & 0.2 & 0.306 & 0.301 & 0.0050 & 0.0166 & $\mathrm{No}^{\mathrm{a}}$ & \\
\hline 2 & 30 & 0.2 & 0.306 & 0.302 & 0.0042 & 0.0139 & $\mathrm{No}^{\mathrm{a}}$ & \\
\hline 2 & 40 & 0.2 & 0.306 & 0.302 & 0.0038 & 0.0126 & $\mathrm{No}^{\mathrm{a}}$ & \\
\hline & & & & & & & & \\
\hline
\end{tabular}




\begin{tabular}{|c|c|c|c|c|c|c|c|c|}
\hline Series & $\mathrm{T}\left({ }^{\circ} \mathrm{C}\right)$ & $\begin{array}{c}{[\mathrm{TODGA}]} \\
(\mathrm{mol} / \mathrm{L})\end{array}$ & $\begin{array}{c}{\left[\mathrm{HNO}_{3}\right]} \\
(\mathrm{aq}, \mathrm{ini}) \\
(\mathrm{mol} / \mathrm{L})\end{array}$ & $\begin{array}{c}{\left[\mathrm{HNO}_{3}\right]} \\
(\mathrm{aq}, \mathrm{eq}) \\
(\mathrm{mol} / \mathrm{L})\end{array}$ & $\begin{array}{c}{\left[\mathrm{HNO}_{3}\right]} \\
(\mathrm{org}, \mathrm{eq}) \\
(\mathrm{Mol} / \mathrm{L})\end{array}$ & $\mathrm{D}$ & $\begin{array}{c}\text { Used in } \\
\text { Fitting? }\end{array}$ & $\begin{array}{c}\text { Estimated } \\
\text { error }\end{array}$ \\
\hline 2 & 50 & 0.2 & 0.306 & 0.303 & 0.0034 & 0.0112 & $\mathrm{No}^{\mathrm{a}}$ & \\
\hline 2 & 10 & 0.2 & 1.020 & 0.963 & 0.0574 & 0.0596 & Yes & $4.6 \%$ \\
\hline 2 & 20 & 0.2 & 1.020 & 0.977 & 0.0430 & 0.0440 & Yes & $4.8 \%{ }^{\mathrm{d}}$ \\
\hline 2 & 30 & 0.2 & 1.020 & 0.983 & 0.0372 & 0.0379 & Yes & $4.9 \%$ \\
\hline 2 & 40 & 0.2 & 1.020 & 0.988 & 0.0322 & 0.0326 & Yes & $5 \%$ \\
\hline 2 & 50 & 0.2 & 1.020 & 0.991 & 0.0294 & 0.0297 & Yes & $5.1 \%$ \\
\hline 2 & 10 & 0.2 & 3.050 & 2.803 & 0.2470 & 0.0881 & Yes & $3.6 \%$ \\
\hline 2 & 20 & 0.2 & 3.050 & 2.824 & 0.2260 & 0.0800 & Yes & $3.7 \% \mathrm{e}$ \\
\hline 2 & 30 & 0.2 & 3.050 & 2.836 & 0.2140 & 0.0755 & Yes & $3.7 \%$ \\
\hline 2 & 40 & 0.2 & 3.050 & 2.849 & 0.2010 & 0.0706 & Yes & $3.8 \%$ \\
\hline 2 & 50 & 0.2 & 3.050 & 2.858 & 0.1920 & 0.0672 & Yes & $3.8 \%$ \\
\hline
\end{tabular}

a Points at less than $0.6 \mathrm{M} \mathrm{HNO}_{3}(\mathrm{aq})(\mathrm{eq})$ excluded from fitting

bcde Points also included with Table SI 3 data in fitting of TODGA / octanol cross complexes. In this context estimated errors were b: $6.5 \%$, c: $6.1 \%$, d: $6.3 \%$ e: $5.9 \%$

Errors quoted above are one standard deviation as reported by gPROMS. The absolute measurement errors are calculated by $\sigma=\omega|x|^{\vee}$ where $\sigma$ is the standard deviation, $\omega$ and $\gamma$ are constants fitted in gPROMS (giving values 0.02932 and 0.8435 respectively) and $\mathrm{x}$ is the measured value (in this case organic acidity). Errors at very low acidity, not included in the gPROMS fitting are likely to be larger than given by this formula.

\section{Speciation Predictions for Nitric Acid, Octanol and TODGA}

Table SI 5: Predicted speciation of extracted nitric acid for selected cases.

\begin{tabular}{|c|c|c|c|c|c|c|c|c|c|c|c|c|c|}
\hline \multicolumn{3}{|c|}{ Conditions } & \multicolumn{11}{|c|}{ Percentage of Extracted Acid in each Complex } \\
\hline $\begin{array}{c}\text { TODGA] } \\
(\mathrm{M})\end{array}$ & $\begin{array}{c}{[\mathrm{Oct}]} \\
(\mathrm{M})\end{array}$ & $\begin{array}{c}{\left[\mathrm{HNO}_{3}\right]} \\
(\mathrm{aq})(\mathrm{eq}) \\
(\mathrm{M})\end{array}$ & $\begin{array}{c}\mathrm{HNO}_{3} . \\
\text { Oct }\end{array}$ & $\begin{array}{c}\mathrm{HNO}_{3} . \\
2 \mathrm{ct}\end{array}$ & $\begin{array}{c}\mathrm{HNO}_{3} . \\
3 \mathrm{Oct}\end{array}$ & $\begin{array}{l}\mathrm{HNO}_{3} . \\
\text { TODGA }\end{array}$ & $\begin{array}{l}2 \mathrm{HNO}_{3} . \\
\text { TODGA }\end{array}$ & $\begin{array}{l}3 \mathrm{HNO}_{3} . \\
\text { TODGA } \\
\end{array}$ & $\begin{array}{l}4 \mathrm{HNO}_{3} . \\
\text { TODGA }\end{array}$ & $\begin{array}{l}2 \mathrm{HNO}_{3} . \\
2 \mathrm{TODGA}\end{array}$ & \begin{tabular}{|c|}
$2 \mathrm{HNO}_{3}$. \\
TODGA. \\
3Oct \\
\end{tabular} & \begin{tabular}{|c|}
$3 \mathrm{HNO}_{3}$. \\
TODGA. \\
$2 \mathrm{Oct}$ \\
\end{tabular} & $\begin{array}{c}\mathrm{HNO}_{3} . \\
\text { TODGA. } \\
\text { Oct } \\
\end{array}$ \\
\hline 0.1 & 0.316 & 2.5 & 7.031 & 0.417 & 0.021 & 25.807 & 12.415 & 0.376 & 0.025 & 3.219 & 4.929 & 13.983 & 31.776 \\
\hline 0.2 & 0.316 & 2.5 & 2.964 & 0.142 & $5.86 \mathrm{E}-3$ & 30.038 & 14.451 & 0.438 & 0.029 & 8.363 & 3.032 & 10.637 & 29.901 \\
\hline 0.3 & 0.316 & 2.5 & 1.704 & 0.070 & 2.47E-3 & 31.621 & 15.212 & 0.461 & 0.030 & 13.790 & 1.997 & 8.191 & 26.921 \\
\hline 0.2 & 0.316 & 0.1 & 0.953 & 0.039 & $1.35 \mathrm{E}-3$ & 53.701 & 0.037 & $1.64 \mathrm{E}-6$ & $1.57 \mathrm{E}-10$ & 0.102 & $4.74 \mathrm{E}-3$ & $2.85 \mathrm{E}-5$ & 45.162 \\
\hline 0.2 & 0.316 & 2.0 & 2.251 & 0.106 & $4.33 \mathrm{E}-3$ & 36.371 & 10.075 & 0.176 & $6.66 \mathrm{E}-3$ & 9.159 & 2.023 & 4.147 & 35.680 \\
\hline 0.2 & 0.316 & 5.0 & 5.235 & 0.164 & $4.40 \mathrm{E}-3$ & 8.047 & 24.290 & 4.618 & 1.908 & 1.390 & 1.413 & 47.708 & 5.223 \\
\hline 0.2 & 0.630 & 2.5 & 5.790 & 0.568 & 0.048 & 15.514 & 7.463 & 0.226 & 0.015 & 2.337 & 13.423 & 23.011 & 31.605 \\
\hline 0.2 & 2.497 & 2.5 & 16.085 & 7.873 & 3.320 & 0.466 & 0.224 & $6.79 \mathrm{E}-3$ & $4.47 \mathrm{E}-4$ & $3.78 \mathrm{E}-3$ & 50.084 & 17.203 & 4.734 \\
\hline
\end{tabular}


Table SI 6: Predicted speciation of octanol for selected cases.

\begin{tabular}{|c|c|c|c|c|c|c|c|c|c|c|}
\hline \multicolumn{3}{|c|}{ Conditions } & \multicolumn{8}{|c|}{ Percentage of Octanol in each Complex } \\
\hline $\begin{array}{c}\text { [TODGA] } \\
(\mathrm{M})\end{array}$ & $\begin{array}{c}\text { [Oct] } \\
(\mathrm{M})\end{array}$ & $\begin{array}{c}{\left[\mathrm{HNO}_{3}\right]} \\
(\mathrm{aq})(\mathrm{eq}) \\
(\mathrm{M})\end{array}$ & Free Oct & $\begin{array}{c}\mathrm{HNO}_{3} . \\
\text { Oct }\end{array}$ & $\begin{array}{c}\mathrm{HNO}_{3} . \\
2 \mathrm{Oct}\end{array}$ & $\begin{array}{c}\mathrm{HNO}_{3} . \\
30 \mathrm{ct}\end{array}$ & $\begin{array}{c}2 \mathrm{HNO}_{3} . \\
\text { TODGA. } \\
\text { 3Oct }\end{array}$ & $\begin{array}{c}3 \mathrm{HNO}_{3} . \\
\text { TODGA. } \\
2 \mathrm{Oct}\end{array}$ & $\begin{array}{c}\mathrm{HNO}_{3} . \\
\text { TODGA. } \\
\text { Oct }\end{array}$ & $\begin{array}{c}\text { TODGA. } \\
20 \mathrm{ct}\end{array}$ \\
\hline 0.1 & 0.316 & 2.5 & 72.274 & 2.168 & 0.257 & 0.020 & 2.280 & 2.874 & 9.797 & 10.330 \\
\hline 0.2 & 0.316 & 2.5 & 58.430 & 1.753 & 0.168 & 0.010 & 2.689 & 4.194 & 17.683 & 15.073 \\
\hline 0.3 & 0.316 & 2.5 & 49.974 & 1.499 & 0.123 & $6.51 \mathrm{E}-3$ & 2.635 & 4.805 & 23.688 & 17.270 \\
\hline 0.2 & 0.316 & 0.1 & 49.365 & $2.15 \mathrm{E}-3$ & $1.74 \mathrm{E}-4$ & $9.09 \mathrm{E}-6$ & $1.60 \mathrm{E}-5$ & $4.28 \mathrm{E}-8$ & 0.102 & 50.531 \\
\hline 0.2 & 0.316 & 2.0 & 57.584 & 0.995 & 0.094 & $5.73 \mathrm{E}-3$ & 1.341 & 1.221 & 15.763 & 22.997 \\
\hline 0.2 & 0.316 & 5.0 & 38.102 & 7.171 & 0.448 & 0.018 & 2.903 & 43.568 & 7.155 & 0.634 \\
\hline 0.2 & 0.630 & 2.5 & 59.889 & 1.796 & 0.352 & 0.045 & 6.247 & 4.760 & 9.806 & 17.106 \\
\hline 0.2 & 2.497 & 2.5 & 75.466 & 2.264 & 2.216 & 1.402 & 10.572 & 1.614 & 0.666 & 5.801 \\
\hline
\end{tabular}

Table SI 7: Predicted speciation of TODGA for selected cases.

\begin{tabular}{|c|c|c|c|c|c|c|c|c|c|c|c|c|}
\hline \multicolumn{3}{|c|}{ Conditions } & \multicolumn{10}{|c|}{ Percentage of TODGA in each Complex } \\
\hline $\begin{array}{c}\text { [TODGA] } \\
(\mathrm{M}) \\
\end{array}$ & $\begin{array}{c}\text { [Oct] } \\
(\mathrm{M}) \\
\end{array}$ & $\begin{array}{c}{\left[\mathrm{HNO}_{3}\right]} \\
(\mathrm{aq})(\mathrm{eq}) \\
(\mathrm{M})\end{array}$ & $\begin{array}{c}\text { Free } \\
\text { TODGA }\end{array}$ & $\begin{array}{l}\mathrm{HNO}_{3} . \\
\text { TODGA }\end{array}$ & $\begin{array}{l}2 \mathrm{HNO}_{3} . \\
\text { TODGA }\end{array}$ & $\begin{array}{l}3 \mathrm{HNO}_{3} . \\
\text { TODGA }\end{array}$ & $\begin{array}{l}4 \mathrm{HNO}_{3} . \\
\text { TODGA }\end{array}$ & $\begin{array}{c}2 \mathrm{HNO}_{3} . \\
2 \mathrm{TODGA}^{2}\end{array}$ & $\begin{array}{c}2 \mathrm{HNO}_{3} . \\
\text { TODGA. } \\
\text { 3Oct }\end{array}$ & $\begin{array}{c}3 \mathrm{HNO}_{3} . \\
\text { TODGA. } \\
2 \mathrm{ct}\end{array}$ & $\begin{array}{c}\mathrm{HNO}_{3} . \\
\text { TODGA. } \\
\text { Oct }\end{array}$ & $\begin{array}{c}\text { TODGA. } \\
\text { 20ct }\end{array}$ \\
\hline 0.1 & 0.316 & 2.5 & 11.399 & 25.122 & 6.043 & 0.122 & $6.03 \mathrm{E}-3$ & 3.133 & 2.399 & 4.537 & 30.932 & 16.307 \\
\hline 0.2 & 0.316 & 2.5 & 12.725 & 28.042 & 6.745 & 0.136 & $6.73 \mathrm{E}-3$ & 7.808 & 1.415 & 3.310 & 27.914 & 11.897 \\
\hline 0.3 & 0.316 & 2.5 & 13.287 & 29.281 & 7.043 & 0.142 & $7.02 \mathrm{E}-3$ & 12.770 & 0.924 & 2.528 & 24.929 & 9.087 \\
\hline 0.2 & 0.316 & 0.1 & 59.764 & 0.191 & $6.65 \mathrm{E}-5$ & 1.95E-09 & $1.39 \mathrm{E}-13$ & $3.62 \mathrm{E}-4$ & $8.42 \mathrm{E}-6$ & $3.38 \mathrm{E}-8$ & 0.161 & 39.884 \\
\hline 0.2 & 0.316 & 2.0 & 19.989 & 25.364 & 3.513 & 0.041 & $1.16 \mathrm{E}-3$ & 6.388 & 0.705 & 0.964 & 24.883 & 18.152 \\
\hline 0.2 & 0.316 & 5.0 & 1.258 & 17.400 & 26.263 & 3.329 & 1.031 & 3.006 & 1.528 & 34.389 & 11.295 & 0.500 \\
\hline 0.2 & 0.630 & 2.5 & 6.884 & 15.171 & 3.649 & 0.074 & $3.64 \mathrm{E}-3$ & 2.285 & 6.563 & 7.501 & 30.908 & 26.960 \\
\hline 0.2 & 2.497 & 2.5 & 0.371 & 0.818 & 0.197 & 3.97E-03 & $1.96 \mathrm{E}-4$ & 6.64E-03 & 43.999 & 10.075 & 8.317 & 36.211 \\
\hline
\end{tabular}

